\title{
Flash vacuum pyrolysis of 1,2,5-oxadiazole 2-oxides and 1,2,3-triazole 1-oxides
}

\author{
William R. Mitchell and R. Michael Paton* \\ School of Chemistry, The University of Edinburgh, The King's Buildings, West Mains Road, \\ Edinburgh, EH9 3JJ, UK \\ E-mail: R.M.Paton@ed.ac.uk
}

\begin{abstract}
The flash vacuum pyrolysis (FVP, $450-600^{\circ} \mathrm{C} / 10^{-3} \mathrm{mmHg}$ ) of 3,4-diaryl- and 3,4-dialkyl-1,2,5oxadiazole 2-oxides (furoxans) has been investigated. In all cases the 1,2,5-oxadiazole ring cleaved cleanly at $\mathrm{O}(1)-\mathrm{N}(2)$ and $\mathrm{C}(3)-\mathrm{C}(4)$ to afford two nitrile oxide fragments, which were trapped in high yield (75-97\%) as their isoxazoline cycloadducts by reaction with alk-1-enes. At higher temperatures $\left(700-800{ }^{\circ} \mathrm{C}\right)$ isocyanates were formed as by-products. The dimerisation of acetonitrile oxide to dimethylfuroxan was followed by ${ }^{1} \mathrm{H}$ NMR spectroscopy, and the rate constant for the $2^{\text {nd }}$ order reaction determined. The furoxans were converted into isocyanates in good yield (61-95\%) by FVP, followed by sulfur dioxide-mediated isomerisation of the resulting nitrile oxides. 2,4,5-Trisubstituted-1,2,3-triazole 1-oxides showed greater thermal stability, but at 700-800 ${ }^{\circ} \mathrm{C}$ decomposition of the 4,5-dimethyl compound 25b lead to 1,2-di(5-methyl-2-phenyl1,2,3-triazol-2-yl)ethane as the major product; attempts to trap acetonitrile oxide were unsuccessful.
\end{abstract}

Keywords: 1,2,5-Oxadiazole 2-oxides, flash vacuum pyrolysis, nitrile oxides, 1,3-dipolar cycloaddition, isocyanates, 1,2,3-triazole 1-oxides

\section{Introduction}

1,2,5-Oxadiazole 2-oxides (furoxans) $\mathbf{1}$ have often been regarded as unwanted by-products formed during the 1,3-dipolar cycloaddition reactions of nitrile oxides 2 . $^{1}$ Thus, when isolated nitrile oxides are used, or even when they are generated in situ, then the nitrile oxide dimer $\mathbf{1}$ may be formed in addition to the target cycloadduct, particularly with less reactive dipolarophiles (Scheme 1). However, it has also been shown that the reverse reaction, involving cleavage of the furoxan ring at $\mathrm{O}(1)-\mathrm{N}(2)$ and $\mathrm{C}(3)-\mathrm{C}(4)$, can provide a useful source of nitrile oxides, ${ }^{2}$ especially when it is inconvenient to generate the nitrile oxides by traditional methods, such as dehydrohalogenation of hydroximoyl halides $\mathbf{3}$ or dehydration of nitromethyl 
compounds. For example, dodecane(dinitrile oxide) 4 and cyclopentane-1,3-bis(carbonitrile oxide) 5 can be generated from the readily accessible cyclododecanofuroxan 6 and the norbornanofuroxan 7 , respectively. ${ }^{2 \mathrm{c}, 2 \mathrm{~g}, 2 \mathrm{i}, 21}$

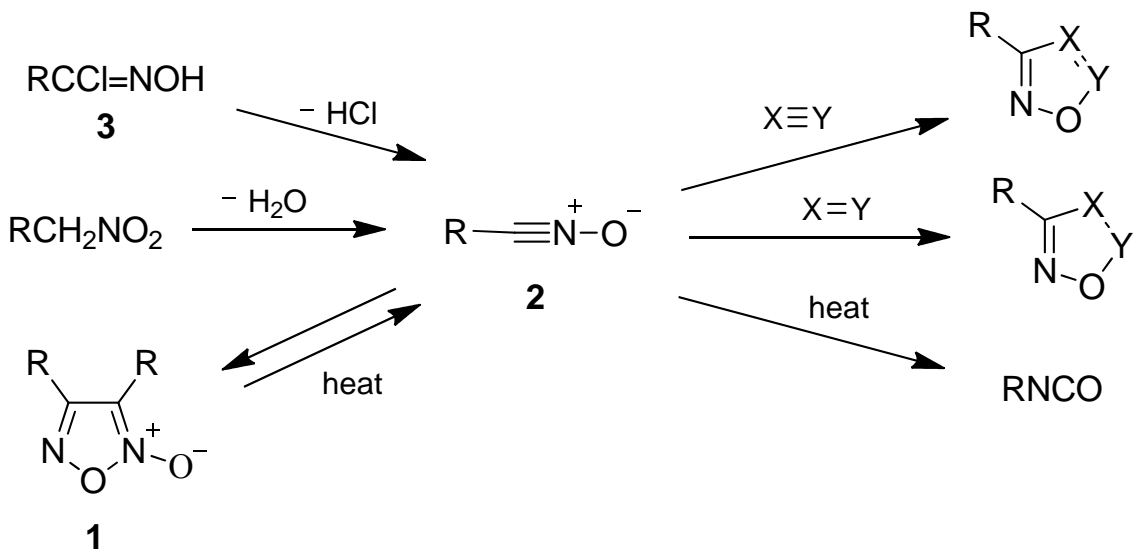

Scheme 1. $\left[\mathrm{R}=\mathbf{a} \mathrm{Ph} ; \mathbf{b} \mathrm{Me} ; \mathbf{c} \mathrm{Et} ; \mathbf{d} \mathrm{EtO}_{2} \mathrm{C} ; \mathbf{e} 4-\mathrm{MeOC}_{6} \mathrm{H}_{4} ; \mathbf{f} 4-\mathrm{ClC}_{6} \mathrm{H}_{4} ; \mathbf{g} 4-\mathrm{MeC}_{6} \mathrm{H}_{4} ; \mathbf{h} \mathrm{Bu}\right]$.<smiles>[O-][N+]=CCCC=[N+]([O-])[O-]</smiles>

4

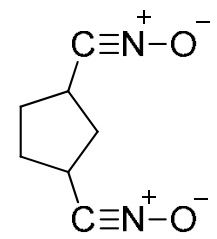

5

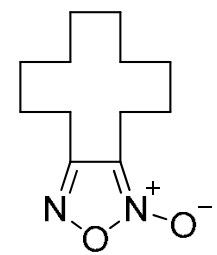

6

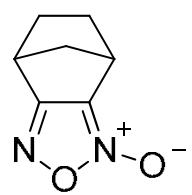

7
$\mathrm{PhNHCO}_{2} \mathrm{C}_{12} \mathrm{H}_{25}$

8<smiles>[R]C1=NOC([R])C1</smiles>

9

The earliest reports concerning the thermolytic cleavage of a furoxan date from 1886 when it was noted that phenyl isocyanate was among the decomposition products when diphenylfuroxan 1a was heated above $200{ }^{\circ} \mathrm{C}$. ${ }^{3}$ Further evidence for the formation of the isocyanate was obtained when the furoxan was heated in refluxing dodecanol $\left(257^{\circ} \mathrm{C}\right)$ and the carbamate 8 isolated in good yield. ${ }^{2 \mathrm{c}} \mathrm{A}$ reaction pathway involving initial cleavage of the furoxan to benzonitrile oxide, followed by the known nitrile oxide to isocyanate rearrangement, was supported by the trapping of the nitrile oxide 2a as its isoxazoline cycloadduct $9\left(\mathrm{R}=\mathrm{Ph}, \mathrm{R}^{\prime}=\mathrm{C}_{12} \mathrm{H}_{25}\right)$ during the corresponding reaction in tetradec-1-ene at $245{ }^{\circ} \mathrm{C} .{ }^{2 \mathrm{c}}$ Furoxans bearing bulky substituents (eg $\mathbf{1}$, $\mathrm{R}=\mathrm{Bu}^{t}$, adamant-1-yl) fragment at more moderate temperatures $\left(80-150{ }^{\circ} \mathrm{C}\right),{ }^{2 \mathrm{~b}, 2 \mathrm{f}}$ and ringstrained analogues such as acenaphthofuroxan and the norbornanofuroxan 7 are also cleaved in the temperature range $50-120{ }^{\circ} \mathrm{C}$ to yield products derived from the bis(carbonitrile oxides), eg 5. ${ }^{2 \mathrm{a}, 2 \mathrm{i}, 21}$ Thermolysis of various furoxans has also allowed unstable nitrile oxides to be studied spectroscopically in the gas phase. ${ }^{4}$

As indicated above, the formation of isoxazoline $9\left(\mathrm{R}=\mathrm{Ph}, \mathrm{R}^{\prime}=\mathrm{C}_{12} \mathrm{H}_{25}\right)$ from furoxan 1a and tetradecene was assumed ${ }^{2 \mathrm{c}}$ to proceed via initial cleavage to benzonitrile oxide (Scheme 2, Path A). However, the nitrile oxide was not detectable under the reaction conditions and the 
possibility of the dipolarophile reacting directly with the $\mathrm{C}=\mathrm{N}^{+}-\mathrm{O}^{-}$moiety of the furoxan to give the nitrone-type adduct 10, followed by fragmentation to $\mathbf{9}$, could not be excluded (Scheme 2, Path B). Such nitrone-like behaviour for some furoxans has since been well established by the work of Shimizu et $a l^{2 \mathrm{~h}, 5}$ and of Butler et al. ${ }^{6}$ For example, bis(ethoxycarbonyl)furoxan 1d reacts with various alkenes to afford the bicyclic products $\mathbf{1 1}$ that incorporate two dipolarophile units. The proposed mechanism in this case involves initial formation of the nitrone adduct $\mathbf{1 0}$, followed by extrusion of ethyl cyanoformate, and cycloaddition of the resulting nitronate 12 to the second alkene (Scheme 2, Path C). ${ }^{5}$ Butler et al showed that such reactions are not dependent on the presence of electron-withdrawing substituents in the furoxan; even the diphenyl and dimethyl furoxans, $\mathbf{1 a}$ and $\mathbf{1 b}$, undergo nitrone-like cycloadditions to $\mathrm{N}$-arylmaleimides and maleic anhydride. ${ }^{6}$<smiles>[R]c1no[n+]([O-])c1[R]</smiles>

1
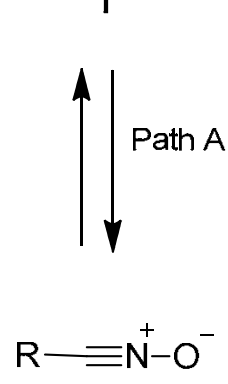

2
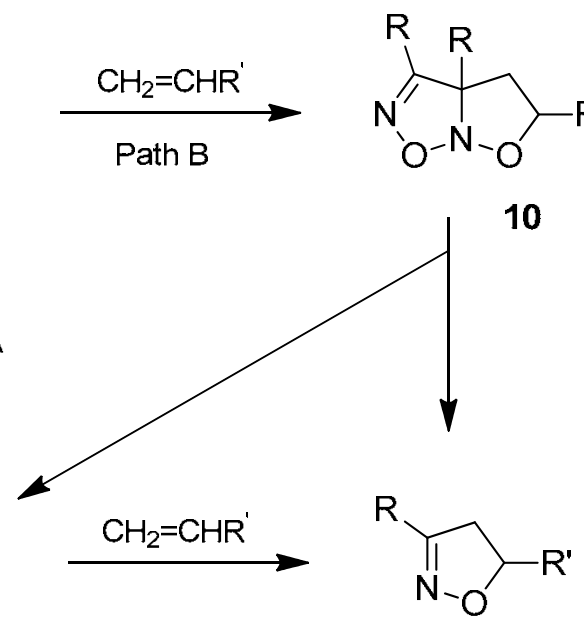

9

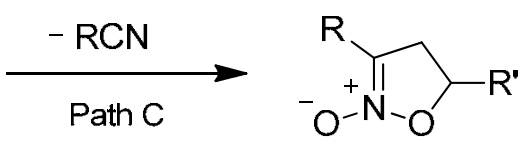

12

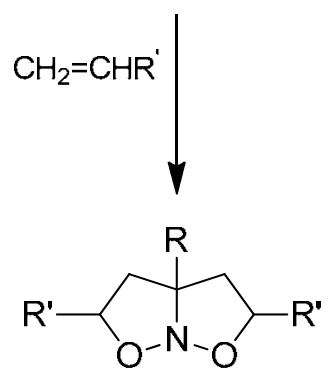

11

Scheme 2. [a $\left.\mathrm{R}=\mathrm{Ph} ; \mathbf{d} \mathrm{EtO}_{2} \mathrm{C}\right]$.

We have recently described the use of flash vacuum pyrolysis (FVP) technique ${ }^{7,8}$ to study the corresponding furazans $(1,2,5$-oxadiazoles) and found that under these conditions they cleaved cleanly at $\mathrm{O}(1)-\mathrm{N}(2)$ and $\mathrm{C}(3)-\mathrm{C}(4)$ to afford the nitrile oxide and nitrile fragments. ${ }^{9}$ In an attempt to isolate nitrile oxides from furoxans, and thus provide evidence for Path A as the route to the isoxazolines $\mathbf{9}$, we have made use of the same approach. ${ }^{10} \mathrm{We}$ also report on the thermal stability of the related 4,5-disubstituted 1,2,3-triazole 1-oxides under FVP conditions.

\section{Results and Discussion}

The furoxans under investigation were all prepared by literature routes ${ }^{1,11}$ involving, either oxidation of the corresponding glyoxime using aq. sodium hypochlorite after the method of Boyer, ${ }^{12}$ or dimerisation of the nitrile oxide. These nitrile oxides were generated in situ by 
dehydration of the appropriate nitromethyl compound using phenyl isocyanate, ${ }^{13}$ or by baseinduced dehydrochlorination of the hydroximoyl chloride (Scheme 1); the latter were conveniently prepared from the aldehyde without unwanted chlorination of the aromatic ring using nitrosyl chloride as reported by Kinney et al. ${ }^{14}$

Pilot FVP experiments were carried out with diphenylfuroxan 1a over a range of temperatures and it was established that at $450{ }^{\circ} \mathrm{C} / 10^{-3} \mathrm{mmHg}$ all the starting material had been consumed. The presence of benzonitrile oxide 2a in the pyrolysate was indicated by its characteristic IR peak at $2281 \mathrm{~cm}^{-1}$ and by comparison with an authentic sample prepared by base treatment of benzohydroximoyl chloride 3a. ${ }^{1}$ Further confirmation of the identity of the product was obtained by reacting it with diethyl fumarate and isolating in high yield (85\%) the known cycloadduct, diethyl trans-3-phenyl-2-isoxazoline-4,5-dicarboxylate $13^{15}$ (Table 1, entry 1).

While conventional methods, such as dehydrochlorination of hydroximoyl halides and dehydrogenation of aldoximes, are satisfactory for the isolation of arene nitrile oxides having long lifetimes, they are less effective for their shorter-lived aliphatic counterparts that undergo rapid dimerisation to the corresponding furoxan. ${ }^{1}$ Thus acetonitrile oxide $\mathbf{2} \mathbf{b}$ has been reported to exist for less than one minute at $18^{\circ} \mathrm{C}$ when isolated, ${ }^{\text {la }}$ although it has been found to be more stable at $-60{ }^{\circ} \mathrm{C}$ and in solution. ${ }^{16}$ In contrast, FVP has the potential to provide a straightforward method for the isolation from readily accessible precursors of short-lived nitrile oxides such as $\mathbf{2 b}$, thus permitting more detailed examination of their spectroscopic properties. To test the approach, dimethylfuroxan $\mathbf{1 b}(0.5 \mathrm{~g}, 4.4 \mathrm{mmol})$ was pyrolysed at $650{ }^{\circ} \mathrm{C}$ and the pyrolysate condensed onto $\mathrm{CDCl}_{3}(\sim 2 \mathrm{ml})$ at $-196^{\circ} \mathrm{C}$; a second layer of $\mathrm{CDCl}_{3}$ was then distilled into the cold trap to form a 'sandwich'. Having generated $\mathbf{2 b}$ it was conveniently stored at $-78{ }^{\circ} \mathrm{C}$ $\left(\mathrm{CO}_{2}\right.$ /acetone slush bath) for several days after which there was no discernable change in its NMR spectra, thus showing that under these conditions recombination back to the furoxan is slow. Using this approach, solutions were prepared of $\mathbf{2 b}$ in $\mathrm{CDCl}_{3}$, and also of the analogous propionitrile oxide 2c, generated by FVP of diethyl furoxan 1c.

The ${ }^{13} \mathrm{C}$ NMR spectrum $\left(\mathrm{CDCl}_{3},-51{ }^{\circ} \mathrm{C}\right)$ of acetonitrile oxide $\mathbf{2 b}$ consisted of two peaks at 35.6 and $0.8 \mathrm{ppm}$, which were assigned to the fulmido $\left(\mathrm{C} \equiv \mathrm{N}^{+}-\mathrm{O}^{-}\right)$and methyl carbons respectively. The signal at $35.6 \mathrm{ppm}$ was a poorly resolved triplet due to coupling to the adjacent ${ }^{14} \mathrm{~N}$ nucleus $\left({ }^{1} J 48 \pm 2 \mathrm{~Hz}\right.$ ). Similarly, the ${ }^{13} \mathrm{C}$ NMR spectrum of propionitrile oxide 2c had a broad partially resolved triplet at $39.1 \mathrm{ppm}$ with a ${ }^{13} \mathrm{C}-{ }^{14} \mathrm{~N}$ coupling of $42 \pm 2 \mathrm{~Hz}$. Poor resolution for fulmido carbon signals has been reported previously ${ }^{17}$ and can be attributed to ${ }^{14} \mathrm{~N}$ nuclear quadrupole relaxation, which is known to cause line broadening. The fulmido $\delta_{\mathrm{C}}$ values for $\mathbf{2 b}$ and 2c are comparable with those reported in the literature for trimethylaceto- $\left(\delta_{\mathrm{C}} 42.2\right){ }^{17 \mathrm{~b}}$ triphenylaceto- $\left(\delta_{\mathrm{C}} 38.4\right)^{17 \mathrm{~b}}$ nitrile oxides, and for 2,4,6-trimethylbenzo- $\left(\delta_{\mathrm{C}} 35.2\right),{ }^{17 \mathrm{a}, 17 \mathrm{~b}} 2,4,6$ trinitrobenzo- $\left(\delta_{\mathrm{C}} 28.9\right),{ }^{17 \mathrm{c}}$ and 4-acetoxy-3-methoxybenzo- $\left(\delta_{\mathrm{C}} 34.4 \mathrm{ppm}\right),{ }^{17 \mathrm{~d}}$ nitrile oxides. ${ }^{1} \mathrm{H}$ NMR signals were observed for $\mathbf{2 b}$ at $2.26 \mathrm{ppm}\left(\mathrm{CH}_{3}\right),{ }^{18}$ and for $2 \mathbf{c}$ at $2.61\left(\mathrm{CH}_{2}\right)$ and $1.30 \mathrm{ppm}$ $\left(\mathrm{CH}_{3}\right)$. On allowing the solution of nitrile oxide $\mathbf{2 b}$ to warm to and remain at room temperature for three days, the peaks attributable to the nitrile oxide disappeared and were replaced by those 
characteristic of the furoxan dimer $1 \mathbf{b}\left[\delta_{\mathrm{C}} 154.4(\mathrm{C}-4), 112.7(\mathrm{C}-3), 10.5,6.9 \mathrm{ppm}\left(\mathrm{CH}_{3}\right) ; \delta_{\mathrm{H}}\right.$ 2.40, $2.21 \mathrm{ppm}\left(\mathrm{CH}_{3}\right)$ ]. Similarly, those for propionitrile oxide (2c) were replaced by those attributable to the corresponding furoxan 1c. The dimerisation of the nitrile oxides could also be monitored the disappearance of the $\mathrm{C} \equiv \mathrm{N}$ peak at $2280 \mathrm{~cm}^{-1}$ in the IR spectrum and the appearance of the characteristic furoxan peak at $1615 \mathrm{~cm}^{-1}$. In addition to allowing the spectroscopic examination of these short-lived aliphatic nitrile oxides, the FVP technique also enables the kinetics of the dimerisation process to be studied in more detail. While the kinetics of nitrile oxide cycloaddition reactions have been investigated in some detail, ${ }^{1}$ there appear to have been few such studies of their dimerisation; ${ }^{17 d, 18}$ those that have been reported concentrated on aryl nitrile oxides, and it has recently been suggested that the dimerisation rate for acetonitrile oxide $\mathbf{2} \mathbf{b}$ is immeasurably fast. ${ }^{19}$ The rates of disappearance of $\mathbf{2} \mathbf{b}$ and the formation of dimer $\mathbf{1 b}$ were found to have the expected second order kinetics. The inclusion of 1,4-dioxan as an internal standard allowed the rate constants to be determined; at $23{ }^{\circ} \mathrm{C}$ the second order rate constant for the formation of furoxan $\mathbf{1 b}$ in $\mathrm{CDCl}_{3}$ was $6.1 \pm 0.2 \times 10^{-4} \mathrm{~mol}^{-1} \mathrm{dm}^{3} \mathrm{~s}^{-1}$. This value compares with those reported for the dimerisations at $25^{\circ} \mathrm{C}$ of 4 -chlorobenzonitrile oxide in $\mathrm{CHCl}_{3}\left(1.77 \times 10^{-4}\right.$ $\left.\mathrm{mol}^{-1} \mathrm{dm}^{3} \mathrm{~s}^{-1}\right),{ }^{18}$ and 4-acetoxy-3-methoxybenzonitrile oxide in $\mathrm{C}_{6} \mathrm{D}_{6}\left(1.21 \times 10^{-4} \mathrm{~mol}^{-1} \mathrm{dm}^{3} \mathrm{~s}^{-1}\right)^{17 \mathrm{~d}}$ That the rate constant for the dimerisation of $\mathbf{2 b}$ is greater than those for the 4-chloro- and and 4acetoxy-3-methoxy-benzonitrile oxides is to be expected; rather, in the light of earlier reports ${ }^{1 \mathrm{c}}$ of the very short lifetime for $\mathbf{2 b}$, it is perhaps surprising that they are so similar.

In addition to the advantages outlined above with respect to the isolation and spectroscopic examination of short-lived aliphatic nitrile oxides, application of FVP could also enhance the synthetic utility of furoxans as nitrile oxide sources. For example, the synthetic route from these furoxans to isoxazolines has been limited by the necessity for the alkene to boil at $>200{ }^{\circ} \mathrm{C}^{2 \mathrm{c}}$ if the reaction is to be carried out at atmospheric pressure. Furthermore, the formation of tarry byproducts was a feature of the original furoxan-based route, which may be attributed to the limited thermal stability of both the dipolarophiles and the resulting cycloadducts. ${ }^{2 \mathrm{c}}$ To test the synthetic utility of this approach a selection of 3,4-disubstitued furoxans were subjected to FVP and the products reacted with alk-1-enes. In a typical experiment diphenylfuroxan $1 \mathrm{a}(0.5 \mathrm{mg}, 2.1 \mathrm{mmol})$ was sublimed $\left(120{ }^{\circ} \mathrm{C} / 10^{-3} \mathrm{mmHg}\right)$, the vapour pyrolysed at $550{ }^{\circ} \mathrm{C} / 10^{-3} \mathrm{mmHg}$, and the pyrolysate condensed into a cold trap at $-196{ }^{\circ} \mathrm{C}$ containing hex-1-ene $(2.0 \mathrm{~g}, 23.8 \mathrm{mmol})$ in dry $\mathrm{Et}_{2} \mathrm{O}$. The product mixture was worked up by removal of the solvent and excess hexene to yield 5-butyl-3-phenyl-2-isoxazoline 9a (97\%) (Table 1, entry 2). Similar results were obtained for the pyrolyses of the di-(4-methoxyphenyl)-, di-(4-chlorophenyl)-, and di-(4-methylphenyl)-furoxans 1e-g (Table 1, entries 3-5), and for the dialkylfurazans 1b,c (Table 1, entries 6,7). The isoxazoline cycloadducts 9a-g were identified from their NMR spectra and by comparison with authentic samples prepared by reaction of the alkene with the appropriate hydroximoyl chloride 3. Their ${ }^{1} \mathrm{H}$ NMR spectra all show the expected ABX pattern for the heterocyclic ring protons (H-4a, H-4b, H-5), and for the 3-methyl compound $9 \mathbf{b}$ there was also an additional longer range coupling $(1.0 \mathrm{~Hz})$ between $\mathrm{H}-4 \mathrm{a} / \mathrm{H}-4 \mathrm{~b}$ and the methyl protons. ${ }^{20}$ 
Table 1. 2-Isoxazolines from $\mathrm{FVP}^{\mathrm{a}}$ of furoxans

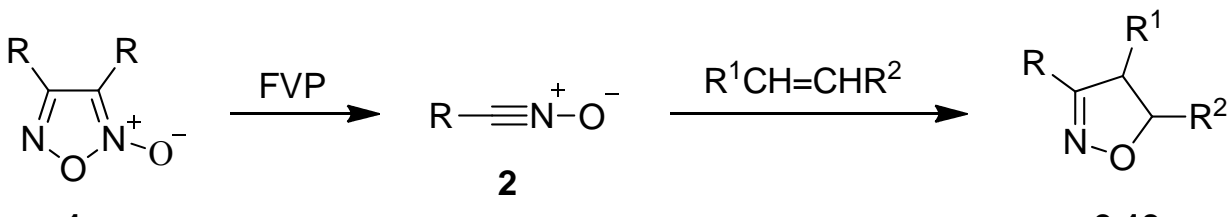

1

9,13

\begin{tabular}{lllllll}
\hline Entry & Furoxan & $\mathrm{R}$ & $\mathrm{R}^{1}$ & $\mathrm{R}^{2}$ & $\begin{array}{l}\text { Oven } \\
\text { Temp. } /{ }^{\circ} \mathrm{C}\end{array}$ & $\begin{array}{l}\text { Product } \\
\text { (Yields / \%) }\end{array}$ \\
\hline 1 & $\mathbf{1 a}$ & $\mathrm{Ph}$ & $\mathrm{EtO}_{2} \mathrm{C}$ & $\mathrm{EtO}_{2} \mathrm{C}$ & 450 & $\mathbf{1 3}(85)$ \\
2 & $\mathbf{1 a}$ & $\mathrm{Ph}$ & $\mathrm{H}$ & $\mathrm{CH}_{3}\left(\mathrm{CH}_{2}\right)_{3}$ & 550 & $\mathbf{9 a}(97)$ \\
3 & $\mathbf{1 e}$ & $4-\mathrm{MeOC}_{6} \mathrm{H}_{4}$ & $\mathrm{H}$ & $\mathrm{CH}_{3}\left(\mathrm{CH}_{2}\right)_{3}$ & 500 & $\mathbf{9 e}(75)$ \\
4 & $\mathbf{1 f}$ & $4-\mathrm{ClC}_{6} \mathrm{H}_{4}$ & $\mathrm{H}$ & $\mathrm{CH}_{3}\left(\mathrm{CH}_{2}\right)_{3}$ & 600 & $\mathbf{9 f}(90)$ \\
5 & $\mathbf{1 g}$ & $4-\mathrm{MeC}_{6} \mathrm{H}_{4}$ & $\mathrm{H}$ & $\mathrm{CH}_{3}\left(\mathrm{CH}_{2}\right)_{11}$ & 500 & $\mathbf{9 g}(86)$ \\
6 & $\mathbf{1 b}$ & $\mathrm{Me}$ & $\mathrm{H}$ & $\mathrm{CH}_{3}\left(\mathrm{CH}_{2}\right)_{3}$ & 600 & $\mathbf{9 b}(75)$ \\
7 & $\mathbf{1 c}$ & $\mathrm{Et}$ & $\mathrm{H}$ & $\mathrm{CH}_{3}\left(\mathrm{CH}_{2}\right)_{3}$ & 650 & $\mathbf{9 c}(95)$ \\
\hline${ }^{\mathrm{a}}$ at $10^{-3} \mathrm{mmHg}$ & & & & &
\end{tabular}

At elevated temperatures nitrile oxides are known to rearrange to isocyanates, ${ }^{1}$ and it was therefore anticipated that, under FVP conditions, isocyanates might be formed as by-products accompanying the isolated nitriles oxides and their cycloadducts. To investigate this possibility diphenylfuroxan 1a was pyrolysed over a range of temperatures, the FVP pyrolysates condensed onto hex-1-ene, and the product mixtures analysed by GC. At $550{ }^{\circ} \mathrm{C}$ the main product was 5butyl-3-phenyl-2-isoxazoline 9a $(98 \%)$ together with traces of phenyl isocyanate $(<2 \%)$. Raising the oven temperature to $700{ }^{\circ} \mathrm{C}$ had little effect on the yield of these products (isoxazoline 9a $95 \%$, PhNCO $4 \%$ ). At $800{ }^{\circ} \mathrm{C}$, however, the combined yield of the two products fell from 99$100 \%$ to $64 \%$; phenyl isocyanate was the main product (37\%) and the yield of isoxazoline 9a reduced to $27 \%$.

In view of the near quantitative combined yield of phenyl isocyanate and isoxazoline 9a from the pyrolysis at $550{ }^{\circ} \mathrm{C}$, the observed ratio $(\mathrm{PhNCO}$ : 9a $=1: 50)$ can be taken as a measure of the relative amounts of phenyl isocyanate and benzonitrile oxide in the pyrolysate. Even at $700{ }^{\circ} \mathrm{C}$ only $4 \% \mathrm{PhNCO}$ is generated. Pyrolysis at $800{ }^{\circ} \mathrm{C}$ did provide more $\mathrm{PhNCO}$, but the yield was still low (37\%). On this evidence FVP does not provide a satisfactory method for converting these furoxans directly into isocyanates. We therefore considered ways by which the efficiency of the nitrile oxide to isocyanate rearrangement could be improved. We have previously established that ring-strained bicyclic furoxans can be converted into diisocyanates in good yield in the presence of sulfur dioxide. For example, the diisocyanate $\mathbf{1 4}$ was prepared from the 
norbornane furoxan 7 by heating in toluene saturated with $\mathrm{SO}_{2} \cdot{ }^{2 \mathrm{i}}$ The furoxans in the present investigation were therefore subjected to FVP at 500-600 ${ }^{\circ} \mathrm{C}$ and the products collected in a cold trap $\left(196{ }^{\circ} \mathrm{C}\right)$ containing an excess of sulfur dioxide. Dry toluene was added and the resulting solution heated at reflux for 1 hour. After removal of the excess sulfur dioxide with a stream of dry nitrogen, the presence of isocyanate was established by IR spectroscopy $\left(v_{\max } \sim 2260 \mathrm{~cm}^{-1}\right)$, by $\mathrm{GC}$ and by reaction with ethanol or aniline to yield the corresponding urethane or urea derivatives respectively. The isocyanates generated by this method are listed in Table 2 .

Table 2. Isocyanates from $\mathrm{FVP}^{\mathrm{a}}$ of furoxans

\begin{tabular}{lllllll}
\hline Entry & Furoxan & $\mathrm{R}$ & $\begin{array}{l}\text { Oven } \\
\text { Temp. } /{ }^{\circ} \mathrm{C}\end{array}$ & $\begin{array}{l}\mathrm{RNCO} \\
/ \%{ }^{\mathrm{b}}\end{array}$ & $\begin{array}{l}\text { RNHCO } \\
/ \%\end{array}$ & $\begin{array}{l}\text { RNHCONHPh } \\
/ \%\end{array}$ \\
\hline 1 & $\mathbf{1 a}$ & $\mathrm{Ph}$ & 500 & 93 & 75 & - \\
2 & $\mathbf{1 g}$ & $4-\mathrm{MeC}_{6} \mathrm{H}_{4}$ & 500 & 76 & - & 71 \\
3 & $\mathbf{1 e}$ & $4-\mathrm{MeOC}_{6} \mathrm{H}_{4}$ & 500 & $\mathrm{c}$ & - & 95 \\
4 & $\mathbf{1 b}$ & $\mathrm{Me}$ & 550 & $\mathrm{c}$ & - & 74 \\
5 & $\mathbf{1 h}$ & $\mathrm{Bu}$ & 600 & $\mathrm{c}$ & - & 61 \\
\hline
\end{tabular}

${ }^{\mathrm{a}}$ at $10^{-3} \mathrm{mmHg} ;{ }^{\mathrm{b}}$ yields determined by GC; ${ }^{\mathrm{c}}$ not determined

The formation of the isocyanates can be explained in terms of initial cleavage of the furoxan under FVP conditions to its two nitrile oxide components, followed by sulfur dioxide-mediated nitrile oxide to isocyanate rearrangement via the 1,3,2,4-dioxathiazole $S$-oxide 15 (Scheme 3). Such a conversion of a nitrile oxide to an isocyanate, which involves 1,3-dipolar cycloaddition of the nitrile oxide to sulfur dioxide yielding 15 followed by its thermal cycloreversion, was first reported by Burk and Carlos, ${ }^{21}$ who used this method to prepare in high yield phenylene-1,4diisocyanate from terephthalodi(nitrile oxide), and later examined in more detail by Trickes and Meier. $^{22}$ In the present work the intermediacy of the dioxathiazole S-oxide 15b derived from dimethylfuroxan $/ \mathrm{SO}_{2}$ was indicated by a characteristic IR peak at $1240 \mathrm{~cm}^{-1},{ }^{21}$ and demonstrated by treatment of the product mixture with water and isolation of the corresponding hydroxamic acid $\left(\mathrm{CH}_{3} \mathrm{CONHOH}\right)$. For dioxathiazole $S$-oxide 15e, formed by pyrolysis of di(4methoxyphenyl)furoxan 1e onto sulfur dioxide, the conversion to 4-methoxyphenyl isocyanate was monitored by the changes in the IR spectrum; on heating in toluene at reflux the peak for 15e at $1240 \mathrm{~cm}^{-1}$ decreased in intensity and was replaced by a new peak for the isocyanate at $2265 \mathrm{~cm}^{-1}$. The sulfur dioxide thus plays a key role by effecting the nitrile oxide to isocyanate conversion at temperatures lower than those normally required, and also by minimising competing dimerisation back to the furoxan. This approach can provide a useful alternative to conventional methods for the generation of the low-boiling and toxic methyl isocyanate, as the dimethylfuroxan precursor is readily available in high yield from nitromethane and also from but-2-ene and dinitrogen trioxide. ${ }^{23}$ 


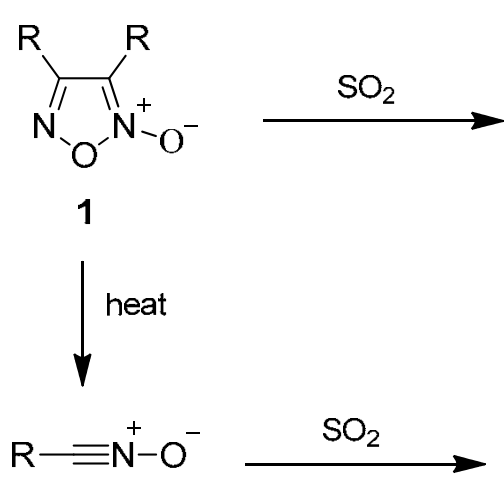

2

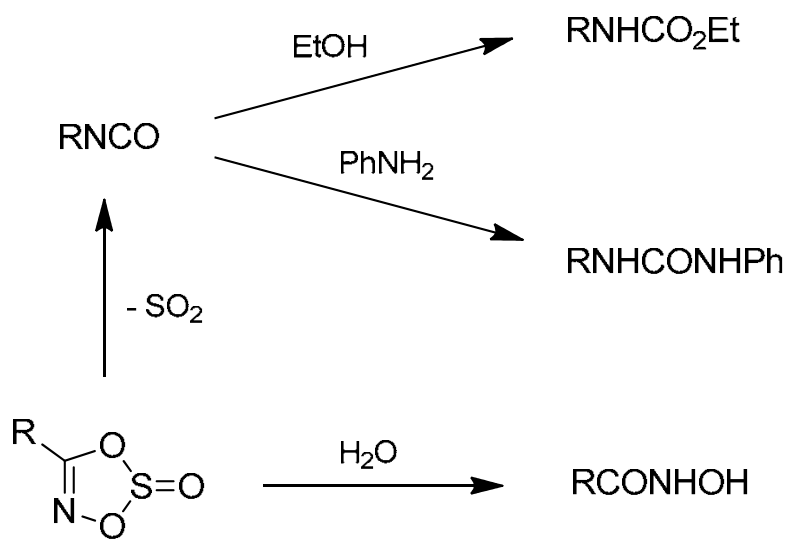

15

Scheme 3. $\left[\mathrm{R}=\mathbf{a} \mathrm{Ph} ; \mathbf{b} \mathrm{Me} ; \mathbf{e} 4-\mathrm{MeOC}_{6} \mathrm{H}_{4}\right]$.<smiles>CCOC(=O)C1ON=C(c2ccccc2)C1C(=O)OCC</smiles>

13

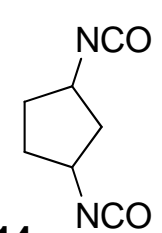

14

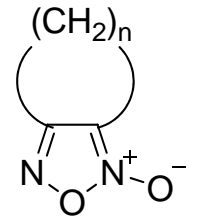

$18 n=3$

$20 n=4$

$21 n=6$

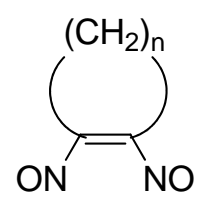

19

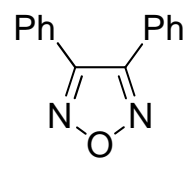

22

The pathway by which the isocyanate is formed from the dioxathiazole $S$-oxide $\mathbf{1 5}$ has not been firmly established. Burk and Carlos showed that cycloaddition of nitrile oxides to $\mathrm{SO}_{2}$ can take place at $-10{ }^{\circ} \mathrm{C}$ to afford 15 , from which the isocyanate can be generated at $125^{\circ} \mathrm{C} .{ }^{21}$ On the other hand, Franz and Pearl found that heating 15a at $110{ }^{\circ} \mathrm{C}$ in the presence of dimethyl acetylenedicarboxylate (DMAD) yielded not only phenyl isocyanate, but also dimethyl isoxazole-4,5-dicarboxylate 16a, the cycloadduct of DMAD and benzonitrile oxide, ${ }^{24}$ suggesting that the isocyanate may be formed by cycloreversion of 15a to the nitrile oxide and its subsequent rearrangement (Scheme 4, path A). In the present work, however, heating 15a in toluene at reflux $\left(\sim 115{ }^{\circ} \mathrm{C}\right)$ in the absence of DMAD yielded phenyl isocyanate in near quantitative yield. Moreover, at these temperatures the rearrangement to isocyanate is much slower than dimerisation to furoxan. ${ }^{25}$ We therefore favour a mechanism involving an equilibrium between $\mathrm{SO}_{2} / \mathrm{RCNO}$ and dioxathiazole $S$-oxide 15 and its subsequent fragmentation at $\mathrm{O}(1)-\mathrm{S}(2)$ and $\mathrm{O}(3)-\mathrm{N}(4)$ with concomitant $\mathrm{C} \rightarrow \mathrm{N}$ migration of the R-group (Scheme 4, path B). Isocyanate formation via Path $\mathrm{B}$ is also supported by studies ${ }^{26}$ using ${ }^{18} \mathrm{O}$-labelled mesitonitrile oxide $\left(2, \mathrm{R}=2,4,6-\mathrm{Me}_{3} \mathrm{C}_{6} \mathrm{H}_{2}\right)$ when the ${ }^{18} \mathrm{O}$ label was detected in the recovered sulfur dioxide. 


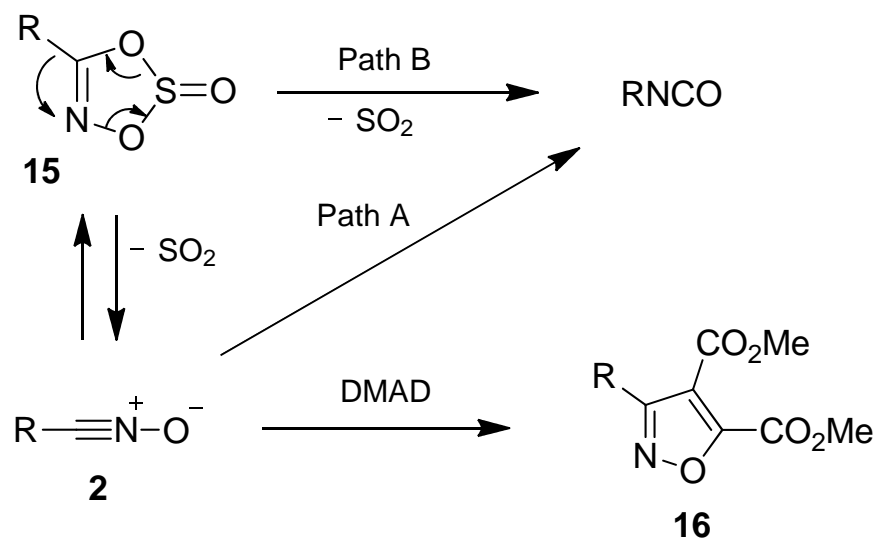

Scheme 4. $[\mathrm{R}=\mathbf{a} \mathrm{Ph} ; \mathbf{b} \mathrm{Me}]$.

A similar approach can be used to convert nitrile oxides into isothiocyanates. Nitrile oxides react readily with several thiocarbonyl compounds to give 1,4,2-oxathiazole cycloadducts; ${ }^{1}$ subsequent thermolysis results in the formation of the isothiocyanate and the oxygen analogue of the original thiocarbonyl compound. ${ }^{27}$ Moreover, if the dipolarophile is a thioamide then the 5amino-1,4,2-oxathiazole cycloadduct is of limited stability and the corresponding amide and isothiocyanate may be obtained directly. ${ }^{27}$ Thus FVP of diphenylfuroxan 1a at $550{ }^{\circ} \mathrm{C}$ onto $\mathrm{N}, \mathrm{N}$ dimethylthioformamide afforded the cycloadduct $\mathbf{1 7}$ which decomposed on warming the pyrolysate to ambient temperature to form phenyl isothiocyanate and $N, N$ dimethylthioformamide (Scheme 5). The phenyl isothiocyanate was identified from its IR spectrum $\left(v_{\max } 2050 \mathrm{~cm}^{-1}\right)$ and by reaction with aniline to yield $N, N^{\prime}$-diphenylthiourea (49\%).

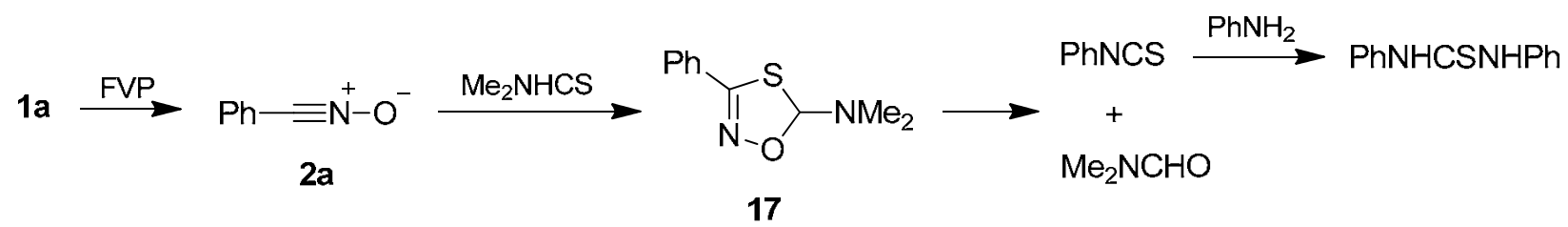

\section{Scheme 5}

As noted earlier, the temperatures required to achieve furoxan ring cleavage are markedly higher for simple dialkyl/aryl furoxans $\left(>200^{\circ} \mathrm{C}\right)$ compared with ring-strained analogues such as the norbornane and trimethylene furoxans, 7 and $18\left(50-120^{\circ} \mathrm{C}\right)$. It is also noteworthy that for the latter group there is more facile equilibration between the 1,2,5-oxadiazole 2- and 5oxides, ${ }^{2 \mathrm{a}, 2 \mathrm{~g}, 11,28,29}$ presumably via the 1,2-dinitrosoalkene tautomer, eg 19. These observations can be explained in terms of the relative weakness of the $\mathrm{O}(1)-\mathrm{N}(2)$ bonds and the differing aromaticities of the furoxan rings. For example, the strained trimethylenefurazan $\mathbf{7}$ has a Bird aromaticity index $\mathrm{I}_{\mathrm{A}}=20.9$, whereas the less strained analogues $\mathbf{2 0}$ and $\mathbf{2 1}$ have $\mathrm{I}_{\mathrm{A}}$ values of 32.2 
and 33.7 respectively. ${ }^{30}$ By this measure the $N$-oxides (furoxans) are less stable than the parent furazans; thus diphenylfuroxan 1a $\left(\mathrm{I}_{\mathrm{A}}=48.9\right)$ is less aromatic than diphenylfurazan $22\left(\mathrm{I}_{\mathrm{A}}=\right.$ 61.9). ${ }^{31}$

Furoxans are not the only heterocyclic $\mathrm{N}$-oxides to behave like nitrones. The $2 \mathrm{H}$-imidazole $\mathrm{N}$-oxide 23 is reported to react with DMAD to afford the adduct $24,{ }^{32}$ and nitrone-like behaviour has also been observed for the related 2,4,5-trisubstituted-1,2,3-triazole-1-oxides 25. Two reaction pathways are also possible for the triazole $N$-oxides 25 (Scheme 6). Direct reaction of the dipolarophile with the nitrone unit $\mathrm{C}(5)=\mathrm{N}(1)-\mathrm{O}$ would give the isoxazolidine 26 (Path $\mathrm{A}$ ), whereas fragmentation at $\mathrm{N}(1)-\mathrm{N}(2)$ and $\mathrm{C}(4)-\mathrm{C}(5)$, analogous to that observed for diaryl and dialkyl furoxans, would yield products derived from nitrile imides and nitrile oxides (Path B). Butler et $a l^{33}$ investigated the reaction of several 1,2,3-triazole-1-oxides with electron-deficient dipolarophiles, but the nitrone cycloadducts were not themselves isolated. Instead rearrangement products were formed; for example tricyclic compound 27 was obtained from the reaction of $N$ phenylmaleimide with triazoline $N$-oxide 25a. It was therefore of interest to examine the thermal stability of such triazoline $N$-oxides under FVP conditions.

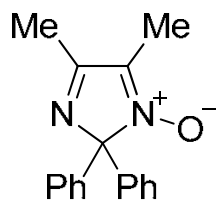

23

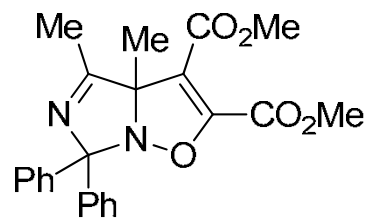

24

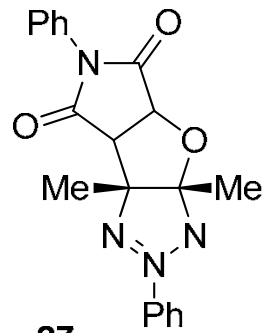

27

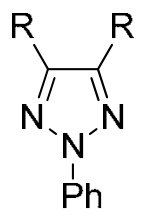

$29 \mathrm{R}=\mathrm{Me}$

$30 \mathrm{R}=\left(\mathrm{CH}_{2}\right)_{4}$

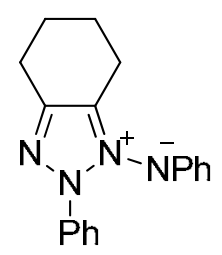

33<smiles>[R]c1nn(-c2ccccc2)c([R])c1[R]</smiles>

26<smiles>[R]c1nn(-c2ccccc2)[n+]([O-])c1[R]</smiles>

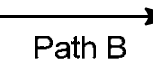

$\mathrm{R}=\stackrel{+}{=}-\mathrm{O}^{-}+\mathrm{R}-\stackrel{+}{=}-\mathrm{N}^{-}-\mathrm{Ph}$

Scheme 6. $[\mathrm{R}=\mathbf{a} \mathrm{Ph} ; \mathbf{b} \mathrm{Me}]$.

The 2,4,5-triphenyl- and 4,5-dimethyl-2-phenyl-1,2,3-triazole 1-oxides 25a and 25b were chosen for investigation. These were prepared from benzil and diacetyl monooxime, respectively, via the corresponding phenylhydrazones, which on oxidation with aq $\mathrm{CuSO}_{4} /$ pyridine, ${ }^{34}$ gave the triazole-1-oxides. Compared with the dialkyl and diaryl furoxans, the triazole $N$-oxides proved to be more stable. The 4,5-diphenyl compound 25a was recovered unchanged after FVP at $650{ }^{\circ} \mathrm{C}$, but the dimethyl analogue 25b proved to be somewhat less stable and above $600{ }^{\circ} \mathrm{C}$ several decomposition products were observed. The pyrolysis products from FVP of compound $\mathbf{2 5 b}$ at $650^{\circ} \mathrm{C}$ were condensed onto hex-1-ene in an attempt to trap any 
acetonitrile oxide and $C$-methyl- $N$-phenyl nitrone that might have been generated. However, TLC analysis of the product mixture showed that none of the expected cycloadduct (5-butyl-3phenyl-2-isoxazoline, 9a) had been formed. Rather, in addition to unreacted starting material, a white crystalline solid was isolated, which was assigned the deoxygenated dimer structure 28 (Scheme 7) on the basis of its spectroscopic properties. The high-resolution mass spectrum (EI) gave a molecular ion $\mathrm{m} / \mathrm{z} 344$, corresponding to the molecular formula $\mathrm{C}_{20} \mathrm{H}_{20} \mathrm{~N}_{6}$ and a main fragment peak at $\mathrm{m} / \mathrm{z} 172\left(\mathrm{C}_{10} \mathrm{H}_{10} \mathrm{~N}_{3}\right)$, consistent with the proposed symmetrical structure. In the ${ }^{13} \mathrm{C}$ spectrum there were distinctive peaks for the carbons of the two equivalent triazole rings at 146.5 (C-4) and $143.5 \mathrm{ppm}(\mathrm{C}-5)$. There were also characteristic ${ }^{1} \mathrm{H}$ and ${ }^{13} \mathrm{C}$ NMR signals for the methyl substituents $\left[\delta_{\mathrm{H}} 2.21 \mathrm{ppm}, \delta_{\mathrm{C}} 9.9 \mathrm{ppm}\right]$ and for the linking ethylidene unit $\left[\delta_{\mathrm{H}} 3.10 \mathrm{ppm}\right.$, $\left.\delta_{\mathrm{C}} 24.1 \mathrm{ppm}\right]$. For comparison, an authentic sample of 4,5-dimethyl-2-phenyl-1,2,3-triazole 29 was prepared by deoxygenation of the corresponding N-oxide 25b. Its NMR data, together with those for compound $\mathbf{2 8}$ and for the tetramethylene analogue $\mathbf{3 0}^{35}$ are shown in Table 3 . The strong correlation between the data for compounds 28, 29 and 30 provides good support for the proposed structure $\mathbf{2 8}$.

Table 3. NMR chemical shifts for 2-phenyl-1,2,3-triazoles ${ }^{\mathrm{a}}$

\begin{tabular}{|c|c|c|c|c|c|c|c|c|c|}
\hline \multirow[t]{2}{*}{ Compound } & \multicolumn{3}{|c|}{$\delta_{\mathrm{H}} / \mathrm{ppm}$} & \multicolumn{6}{|c|}{$\delta_{\mathrm{C}} / \mathrm{ppm}$} \\
\hline & $\mathrm{CH}_{3}$ & $\mathrm{CH}_{2}$ & $\mathrm{C}_{6} \mathrm{H}_{5}$ & $C(4)$ & $C(5)$ & $\mathrm{CH}_{3}$ & $\mathrm{CH}_{2}$ & $\mathrm{PhC}$ & $\mathrm{PhCH}$ \\
\hline \multirow[t]{3}{*}{28} & 2.21 & 3.10 & $7.21-$ & 143.5 & 146.5 & 9.9 & 24.1 & 139.8 & 129.1 \\
\hline & & & 8.05 & & & & & & 126.5 \\
\hline & & & & & & & & & 118.1 \\
\hline \multirow[t]{3}{*}{29} & 2.25 & - & $7.15-$ & 143.5 & 143.5 & 9.8 & - & 139.7 & 128.9 \\
\hline & & & 7.95 & & & & & & 126.9 \\
\hline & & & & & & & & & 117.8 \\
\hline \multirow[t]{3}{*}{$30^{b}$} & - & 2.82 & 7.29 & 145.6 & 145.6 & - & 23.1 & 140.1 & 129.1 \\
\hline & & & 7.99 & & & & & & 126.5 \\
\hline & & & & & & & & & 118.2 \\
\hline
\end{tabular}

${ }^{\mathrm{a}} \mathrm{In} \mathrm{CDCl}_{3} ;{ }^{\mathrm{b}}$ data from ref 35 .

A possible mechanism to account for the formation of compound $\mathbf{2 8}$ is shown in Scheme 7. This involves as the first stage formation of the $N$-hydroxyl tautomer $\mathbf{3 1}$, followed by loss of $\mathrm{OH}$ under the FVP conditions to generate the resonance-stabilised radical 32; subsequent dimerisation leads to the observed product, presumably in the gas phase. A similar mechanism has been invoked by George et $a l^{36}$ to explain the formation of triazole $\mathbf{3 0}$ on irradiation of the triazole $N$-imide 33. These results confirm that 1,2,3-triazole 1-oxides are more stable than the corresponding furoxans, an effect that can be attributed to the relative strength of the $\mathrm{N}-\mathrm{N}$ bond compared with $\mathrm{N}-\mathrm{O}$, and also to the greater aromaticity of the 1,2,3-triazole nucleus $\left(\mathrm{I}_{\mathrm{A}} 109\right)$ compared with the corresponding 1,2,5-oxadiazole $\left(I_{A} 53\right) .{ }^{30}$ A similar trend is expected for the 
corresponding $N$-oxides, the latter being less aromatic. ${ }^{31}$

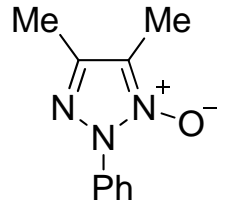

25b

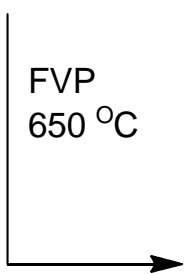

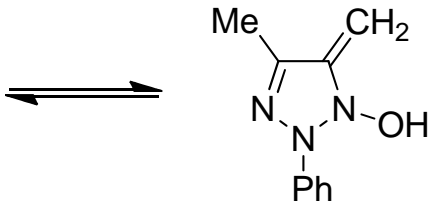

31

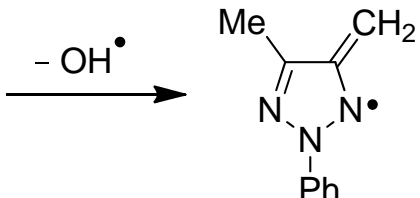

32

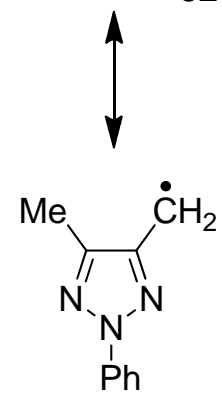

28

\section{Scheme 7}

In conclusion, these results show that the fragmentation of furoxans to nitrile oxides does not depend on special features such as ring strain or bulky substituents, and that the FVP technique gives excellent yields of cleavage products. It is also noteworthy that by using FVP a wider range of dipolarophiles can be employed compared with liquid-phase reactions. For short-lived nitrile oxides, such as acetonitrile oxide, FVP of the corresponding furoxan is a method of choice, the nitrile oxides being obtained in high yield from stable and readily accessible precursors. Isolation of acetonitrile oxide has also allowed the kinetics of its dimerisation to be studied, which showed that it is more stable than anticipated. One synthetic limitation of this approach, however, would be for low reactivity dipolarophiles when recombination back to the furoxan may dominate the desired cycloaddition reaction; in these cases generation by traditional methods in the presence of excess dipolarophile would remain the best approach. Using sulfur dioxide as the dipolarophile provides an efficient method for the conversion of the nitrile oxide fragments into the isomeric isocyanates. The 1,2,3-triazole 1-oxides examined proved to be much more stable and attempts to trap nitrile oxides from their decomposition were not successful.

\section{Experimental Section}

General. The general methods and spectroscopic techniques were as recently reported. ${ }^{9}$ Flash vacuum pyrolysis (FVP) experiments involved volatalisation of the furoxan (or triazole $N$-oxide) under rotary pump pressure through an electrically-heated silica tube $(36 \times 2.0 \mathrm{~cm})$, arranged 
horizontally and packed with $6 \mathrm{~cm}$ lengths of silica tube ( $7 \mathrm{~mm}$ o.d, $5 \mathrm{~mm}$ i.d.). The pyrolysate was condensed into a cold trap $\left(\mathrm{ca}-196^{\circ} \mathrm{C}\right)$ containing an excess of the dipolarophile, and a further layer of the dipolarophile was then added. The reaction mixture was allowed to warm to room temperature under a nitrogen atmosphere and the entire pyrolysate dissolved in a solvent and removed from the trap. The results are summarised in Tables 1 and 2.

\section{Preparation of furoxans}

The furoxans were prepared by one of the following three methods: ${ }^{11 \mathrm{~d}}$

Method 1. Dehydrogenation of the glyoxime using sodium hypochlorite after the method of Boyer. ${ }^{12}$ 3,4-Diphenylfuroxan $9 a^{37}(75 \%)$.

Method 2. Dimerisation of the nitrile oxide, generated by dehydration of the nitromethyl compound, as described by Mukaiyama and Hoshino. ${ }^{13}$ 3,4-Dimethylfuroxan $9 b^{13}(68 \%)$. 3,4Diethylfuroxan $9 c^{38}(40 \%)$.

Method 3. Dimerisation of the nitrile oxide, generated by dehydochlorination of the hydroximoyl chloride, as described by Boulton et al. ${ }^{39}$ 3,4-Bis(4-methoxyphenyl)furoxan $9 \mathbf{e}^{14}(81 \%) .3,4-$ Bis(4-chlorophenyl)furoxan $9 f^{39}$ (88\%). 3,4-Bis(4-methylphenyl)furoxan $9 g^{40}(70 \%)$.

\section{Preparation of 1,2,3-triazoles}

2,4,5-Triphenyl-1,2,3-triazole 1-oxide (25a). A solution of copper(II) sulfate (10.0 g, $40 \mathrm{mmol})$ in water $(70 \mathrm{ml})$ was added over $1 \mathrm{~h}$ to a solution of benzil monooxime phenylhydrazone $(5.0 \mathrm{~g}$, $16 \mathrm{mmol})$ in pyridine $(100 \mathrm{ml})$. The mixture was heated at reflux for $1 \frac{1}{2} \mathrm{~h}$, cooled, and poured onto crushed ice. The resulting solid was extracted with toluene and dried $\left(\mathrm{CaCl}_{2}\right)$. The toluene was evaporated to leave the product $(2.2 \mathrm{~g}, 44 \%)$, which was treated with activated charcoal/EtOH, and recrystallised from EtOH; mp $167{ }^{\circ} \mathrm{C}$ (lit. ${ }^{33 \mathrm{~b}} 168-169{ }^{\circ} \mathrm{C}$ ); IR (Nujol): $v$ $1590 \mathrm{~cm}^{-1}(\mathrm{C}=\mathrm{N})$. Anal. Calcd. for $\mathrm{C}_{20} \mathrm{H}_{15} \mathrm{~N}_{3} \mathrm{O}$ : C, 76.7; H, 4.8; N, 13.4. Found: C, 76.5; H, 4.9; $\mathrm{N}, 13.4$.

4,5-Dimethyl-2-phenyl-1,2,3-triazole 1-oxide (25b). A solution of copper(II) sulfate (25.0 g, $0.10 \mathrm{~mol})$ in water $(70 \mathrm{ml})$ was added over $1 \mathrm{~h}$ to a solution of diacetyl monooxime phenylhydrazone $(9.6 \mathrm{~g}, 0.05 \mathrm{~mol})$ in pyridine $(250 \mathrm{ml})$. The mixture was heated at reflux for $1 \frac{1}{2} \mathrm{~h}$, cooled, and poured onto crushed ice. The resulting solid was extracted with dichloromethane and dried $\left(\mathrm{CaCl}_{2}\right)$. The dichloromethane was evaporated to leave the product $(6.7 \mathrm{~g}, 71 \%)$, which was treated with activated charcoal/EtOH, and recrystallised from EtOH to afford white needles; mp 87-89 ${ }^{\circ} \mathrm{C}$ (lit. $\left.{ }^{41} 92-93{ }^{\circ} \mathrm{C}\right)$; IR (Nujol): $v 1595 \mathrm{~cm}^{-1}(\mathrm{C}=\mathrm{N})$; ${ }^{13} \mathrm{C}$ NMR $\left(\mathrm{CDCl}_{3}\right): \delta 141.3,135.5(\mathrm{C}-4,5), 129.0,128.4,124.5,122.6(\mathrm{ArC}), 11.6,7.6\left(\mathrm{CH}_{3}\right) ; \mathrm{MS}(\mathrm{EI}): \mathrm{m} / \mathrm{z}$ (\%) $189\left(\mathrm{M}^{+}\right), 173\left([\mathrm{M}-\mathrm{O}]^{+}\right), 132\left(\mathrm{MeCNNPh}^{+}\right)$.

4,5-Dimethyl-2-phenyl-1,2,3-triazole (29). A mixture of 4,5-dimethyl-2-phenyl-1,2,3-triazole 1-oxide 25b (20.0 g, $10.6 \mathrm{mmol})$ and triethyl phosphite $(10 \mathrm{ml})$ was heated at reflux under dry nitrogen until HPLC analysis showed that nearly all the triazole $N$-oxide had been consumed. The excess triethyl phosphite was removed by vacuum distillation and the residue poured onto crushed ice. Extraction with diethyl ether, drying $\left(\mathrm{CaCl}_{2}\right)$, and removal of the solvent gave a 
yellow oil. Purification by chromatography (alumina, $\mathrm{CH}_{2} \mathrm{Cl}_{2}$ ) and vacuum distillation $\left(75^{\circ} \mathrm{C} / 0.01 \mathrm{mmHg}\right.$ ) afforded the triazole 29 as a white solid $(77 \%)$; mp $33-35{ }^{\circ} \mathrm{C}$ (lit. ${ }^{41} 34-$ $\left.35{ }^{\circ} \mathrm{C}\right) ;{ }^{1} \mathrm{H}$ NMR $\left(\mathrm{CDCl}_{3}\right): \delta$ 7.95-7.15 (m, 5H, $\left.\mathrm{PhH}\right), 2.25\left(\mathrm{~s}, 3 \mathrm{H}, \mathrm{CH}_{3}\right) ;{ }^{13} \mathrm{C}$ NMR $\left(\mathrm{CDCl}_{3}\right)$ : $\delta 143.5(\mathrm{C}-4,5), 139.7,128.9,126.2,117.8(\mathrm{ArC}), 9.7\left(\mathrm{CH}_{3}\right)$; $\mathrm{MS}(\mathrm{EI}): \mathrm{m} / \mathrm{z}(\%) 173\left(\mathrm{M}^{+}\right)$.

\section{Flash vacuum pyrolysis (FVP) of furoxans}

\section{Preparation of 2-isoxazolines by FVP of furoxans}

Diethyl trans-3-phenyl-2-isoxazoline-4,5-dicarboxylate (13). 3,4-Diphenylfuroxan 1a (500 $\mathrm{mg}, 2.10 \mathrm{mmol})$ was sublimed $\left(120^{\circ} \mathrm{C} / 10^{-3} \mathrm{mmHg}\right)$ and the vapour pyrolysed at $450{ }^{\circ} \mathrm{C}$, and the pyrolysate condensed onto diethyl fumarate $(0.8 \mathrm{~g}, 4.65 \mathrm{mmol})$ in toluene $(5 \mathrm{ml})$. The reaction mixture allowed to warm to room temperature under dry nitrogen and the resulting solution examined by IR spectroscopy. Benzonitrile oxide was identified by the characteristic absorption at $2281 \mathrm{~cm}^{-1}$ and its disappearance was also monitored by IR. The toluene was removed in vacuo and TLC investigation of the residue showed the presence of a single product. Distillation afforded diethyl trans-3-phenyl-2-isoxazoline-4,5-dicarboxylate $13(1.0 \mathrm{~g}, 82 \%)$ as a colourless liquid; bp $132{ }^{\circ} \mathrm{C} / 0.1 \mathrm{mmHg}$ (lit. ${ }^{15} 158-160^{\circ} \mathrm{C} / 0.2 \mathrm{mmHg}$ ); IR (Nujol): $v 1595(\mathrm{C}=\mathrm{N}), 1740 \mathrm{~cm}^{-}$ ${ }^{1}(\mathrm{C}=\mathrm{O})$; the ${ }^{1} \mathrm{H}$ and ${ }^{13} \mathrm{C}$ NMR spectra were indistinguishable from those of an authentic sample.

5-Butyl-3-phenyl-2-isoxazoline (9a). 3,4-Diphenylfuroxan 1a (500 $\mathrm{mg}, 2.10 \mathrm{mmol}$ ) was pyrolysed at $550{ }^{\circ} \mathrm{C}$ and the pyrolysate condensed onto hex-1-ene $(2.0 \mathrm{~g}, 23.8 \mathrm{mmol})$ in dry diethyl ether $(5 \mathrm{ml})$. After warming to room temperature under dry nitrogen the solvent and unreacted hexene were removed in vacuo to leave 5-butyl-3-phenyl-2-isoxazoline 9a $(830 \mathrm{mg}$, 97\%) as white platelets (from EtOH); mp 40-41 ${ }^{\circ} \mathrm{C}$ (lit. ${ }^{42} 41{ }^{\circ} \mathrm{C}$ ); the IR, ${ }^{1} \mathrm{H}$ and ${ }^{13} \mathrm{C}$ NMR spectra were indistinguishable from those previously reported. ${ }^{9}$

5-Butyl-3-methyl-2-isoxazoline (9b). 3,4-Dimethylfuroxan 1b (300 mg, $2.63 \mathrm{mmol}$ ) was pyrolysed at $600{ }^{\circ} \mathrm{C}$ and the pyrolysate condensed onto hex-1-ene $(4.4 \mathrm{~g}, 52.6 \mathrm{mmol})$. After warming to room temperature the unreacted hexene was removed in vacuo to leave the product (580 $\mathrm{mg}, 79 \%)$ as a yellow oil. Vacuum distillation yielded 5-butyl-3-methyl-2-isoxazoline $\mathbf{9 b}$; bp $40{ }^{\circ} \mathrm{C} / 0.02 \mathrm{mmHg}$; the IR, ${ }^{1} \mathrm{H}$ and ${ }^{13} \mathrm{C}$ NMR spectra were indistinguishable from those previously reported. ${ }^{9}$

5-Butyl-3-ethyl-2-isoxazoline (9c). 3,4-Diethylfuroxan 1c (400 mg, $2.80 \mathrm{mmol}$ ) was pyrolysed at $650{ }^{\circ} \mathrm{C}$ and the pyrolysate condensed onto hex-1-ene (10 fold excess). After warming to room temperature the unreacted hexene was removed in vacuo to leave a yellow liquid which, on vacuum distillation, afforded 5-butyl-3-ethyl-2-isoxazoline 9c (830 $\mathrm{mg}, 96 \%$ ); bp $45{ }^{\circ} \mathrm{C} / 0.01$ mmHg; ${ }^{1} \mathrm{H}$ NMR $\left(\mathrm{CDCl}_{3}\right): \delta 4.45(\mathrm{~m}, 1 \mathrm{H}, \mathrm{H}-5), 2.98\left(\mathrm{dd}, J_{4 \mathrm{a}, 4 \mathrm{~b}}=16, J_{4 \mathrm{a}, 5}=10 \mathrm{~Hz}, 1 \mathrm{H}, \mathrm{H}-4 \mathrm{a}\right)$, $2.54\left(\mathrm{dd}, J_{4 \mathrm{~b}, 4 \mathrm{a}}=16, J_{4 \mathrm{~b}, 5}=8 \mathrm{~Hz}, 1 \mathrm{H}, \mathrm{H}-4 \mathrm{~b}\right), 2.33\left(\mathrm{q}, J=8 \mathrm{~Hz}, 2 \mathrm{H}, \mathrm{CH}_{2}\right), 1.14$ (t, $J=8 \mathrm{~Hz}, 3 \mathrm{H}$, $\mathrm{CH}_{3}$ ), 0.8-1.8 (m, 9H, $\left.\mathrm{CH}_{2} / \mathrm{CH}_{3}\right) ;{ }^{13} \mathrm{C}$ NMR $\left(\mathrm{CDCl}_{3}\right): \delta 159.5$ (C-3), 79.8 (C-5), $41.6(\mathrm{C}-4)$, 34.8, 27.4, 22.2, $22.1\left(\mathrm{CH}_{2}\right)$, 13.6, $11.0\left(\mathrm{CH}_{3}\right)$; HRMS (EI): Calcd. for $\mathrm{C}_{9} \mathrm{H}_{17} \mathrm{NO}: M 155.1310$. Found: $m / z 155.1315$. 
5-Butyl-3-(4-methoxyphenyl)-2-isoxazoline (9e). 3,4-Di(4-methoxyphenyl)furoxan 1e (300 $\mathrm{mg}, 1.01 \mathrm{mmol})$ was pyrolysed at $500{ }^{\circ} \mathrm{C}$ and the pyrolysate condensed onto hex-1-ene $(2.0 \mathrm{~g}$, $23.8 \mathrm{mmol})$. After warming to room temperature under dry nitrogen the solvent and unreacted hexene were removed in vacuo to leave 5-butyl-3-(4-methoxyphenyl)-2-isoxazoline $9 \mathrm{e}$ (350 $\mathrm{mg}$, $75 \%$ ) as white platelets (from EtOH/ $\mathrm{H}_{2} \mathrm{O}$ ); mp $85{ }^{\circ} \mathrm{C}$ (lit. ${ }^{9} 82-84{ }^{\circ} \mathrm{C}$ ); the IR, ${ }^{1} \mathrm{H}$ and ${ }^{13} \mathrm{C}$ NMR spectra were indistinguishable from those previously reported. ${ }^{9}$

5-Butyl-3-(4-chlorophenyl)-2-isoxazoline (9f). 3,4-Di(4-chlorophenyl)furoxan 1f (300 mg, $0.98 \mathrm{mmol}$ ) was pyrolysed at $600{ }^{\circ} \mathrm{C}$ and the pyrolysate condensed onto hex-1-ene (10 fold excess). HPLC analysis showed the presence of the product together with traces of unreacted starting material. After removal of the solvent and unreacted hexene the residue was purified by chromatography (silica, $\mathrm{CH}_{2} \mathrm{Cl}_{2}$ ) to yield a white solid that was recrystallised from $\mathrm{MeOH} / \mathrm{H}_{2} \mathrm{O}$ to give 5-butyl-3-(4-chlorophenyl)-2-isoxazoline 9f (420 mg, 90\%); mp 73-74 ${ }^{\circ} \mathrm{C}$ (lit. ${ }^{9} 73-74$ ${ }^{\circ} \mathrm{C}$ ); the IR, ${ }^{1} \mathrm{H}$ and ${ }^{13} \mathrm{C}$ NMR spectra were indistinguishable from those previously reported. ${ }^{9}$

5-Dodecyl-3-(4-methylphenyl)-2-isoxazoline (9g). 3,4-Di(4-methylphenyl)furoxan $\mathbf{1 f}$ (200 mg, $0.78 \mathrm{mmol})$ was pyrolysed at $500{ }^{\circ} \mathrm{C}$ and the pyrolysate condensed onto tetradec-1-ene $(1.5 \mathrm{~g}$, $750 \mathrm{mmol}$ ) in dry diethyl ether. After removal of the solvent the residue was triturated with pentane and the resulting solid was collected by filtration and recrystallised from methanol to afford 5-butyl-3-(4-methylphenyl)-2-isoxazoline 9g (380 mg, 77\%); mp 75-77 ${ }^{\circ} \mathrm{C} ;{ }^{1} \mathrm{H}$ NMR $\left(\mathrm{CDCl}_{3}\right): \delta 7.52$ (d, $\left.J=10 \mathrm{~Hz}, 2 \mathrm{H}, \mathrm{ArH}\right), 7.18(\mathrm{~d}, J=10 \mathrm{~Hz}, 2 \mathrm{H}, \mathrm{ArH}), 4.60$ (m, 1H, H-5), 3.32 $\left(\mathrm{dd}, J_{4 \mathrm{a}, 4 \mathrm{~b}}=16, J_{4 \mathrm{a}, 5} 10 \mathrm{~Hz}, 1 \mathrm{H}, \mathrm{H}-4 \mathrm{a}\right), 2.90$ (dd, $\left.J_{4, \mathrm{b4a}} 16, J_{4 \mathrm{~b}, 5}=8 \mathrm{~Hz}, 1 \mathrm{H}, \mathrm{H}-4 \mathrm{~b}\right), 2.38(\mathrm{~s}, 3 \mathrm{H}$, $\left.\mathrm{CH}_{3}\right)$, 0.7-1.9 (m, 25H, $\left.\mathrm{CH}_{2} / \mathrm{CH}_{3}\right) ;{ }^{13} \mathrm{C} \mathrm{NMR}\left(\mathrm{CDCl}_{3}\right): \delta 156.3$ (C-3), 140.0, 129.3, 127.2, 126.5 (ArC), 81.3 (C-5), 40.1 (C-4), 35.4, 31.9, 29.7, 29.4, 25.6, $22.7\left(15 \times \mathrm{CH}_{2}\right), 21.4,14.1\left(\mathrm{CH}_{3}\right)$. Anal. Calcd. for $\mathrm{C}_{22} \mathrm{H}_{35} \mathrm{NO}$ : C, 80.2; H, 10.6; N, 4.3. Found: C, 80.1; H, 10.8; N, 4.1.

\section{Preparation of isocyanates by FVP furoxans. General procedure}

Sulfur dioxide, dried by passing through a $\mathrm{CaCl}_{2}$ drying tower, was dissolved in dry toluene $(\sim 5 \mathrm{ml})$ and the mixture co-distilled into the FVP cold trap. The furoxan was then sublimed/distilled through the pyrolysis tube $\left(500-650{ }^{\circ} \mathrm{C} / 10^{-3} \mathrm{mmHg}\right)$ and the pyrolysate condensed into the cold trap. A further layer of dry sulfur dioxide was then condensed into the trap and the mixture allowed to warm to room temperature. Dry toluene $(\sim 50 \mathrm{ml})$ was added and the mixture heated at reflux for 1-2 $\mathrm{h}$. Any remaining sulfur dioxide was removed by passing dry nitrogen through the solution and the presence of the isocyanate established by GC and/or reaction with ethanol or aniline to form the urethane or urea derivatives, respectively. The results are summarised in Table 2.

Phenyl isocyanate. 3,4-Diphenylfuroxan 1a $(330 \mathrm{mg}, 1.39 \mathrm{mmol})$ was pyrolysed at $500{ }^{\circ} \mathrm{C}$ and the pyrolysate condensed onto sulfur dioxide. GC analysis on $10 \%$ of the reaction mixture, using nitrobenzene as internal standard, showed the presence of phenyl isocyanate $(2.59 \mathrm{mmol}, 93 \%)$. Dry ethanol $(10 \mathrm{ml})$ and triethylamine $(5$ drops) were added to the remainder of the reaction mixture and the resulting solution stirred for $24 \mathrm{~h}$. The excess ethanol and the solvent were removed in vacuo and the residue vacuum distilled to afford ethyl phenylcarbamate $(340 \mathrm{mg}$, 
75\%); mp and mixed mp 51-53 ${ }^{\circ} \mathrm{C}\left(\right.$ lit. $\left.^{43} 53{ }^{\circ} \mathrm{C}\right)$. The IR spectrum was indistinguishable from that of an authentic sample prepared from phenyl isocyanate and ethanol.

4-Methylphenyl isocyanate. 3,4-Di(4-methylphenyl)furoxan $1 \mathrm{~g}(500 \mathrm{mg}, 1.86 \mathrm{mmol})$ was pyrolysed at $500{ }^{\circ} \mathrm{C}$ and the pyrolysate condensed onto sulfur dioxide. After heating under reflux in toluene the presence of the isocyanate was established by IR spectroscopy $\left(v 2250 \mathrm{~cm}^{-1}\right)$. GC analysis on $10 \%$ of the reaction mixture, using ethyl benzoate as internal standard, showed the presence of $p$-methylphenyl isocyanate $(2.83 \mathrm{mmol}, 76 \%)$. Freshly distilled aniline (excess) was added to the remainder of the reaction mixture and the resulting solution stirred for $12 \mathrm{~h}$. The resulting precipitate of $N$-(4-methylphenyl)- $N^{\prime}$-phenylurea was isolated by filtration and recrystallised from ethanol; $\mathrm{mp} 221-222{ }^{\circ} \mathrm{C}\left(\right.$ lit. $\left.^{43} 226^{\circ} \mathrm{C}\right)$.

4-Methoxyphenyl isocyanate. 3,4-Di(4-methoxyphenyl)furoxan 1e (200 mg, $0.67 \mathrm{mmol})$ was pyrolysed at $500{ }^{\circ} \mathrm{C}$ and the pyrolysate condensed onto sulfur dioxide. After warming to room temperature the mixture was examined by IR spectroscopy which showed the peaks attributable to sulfur dioxide $\left[v 2460,1300,1125 \mathrm{~cm}^{-1}\right]$, the isocyanate $\left[v 2265 \mathrm{~cm}^{-1}\right]$ and the $1,3,2,4-$ dioxathiazole $S$-oxide 15e $\left.\left[v 1243 \mathrm{~cm}^{-1}\right]\right]^{44}$ The solution was heated to reflux and the disappearance of 15e monitored; the intensity of the absorption at $2265 \mathrm{~cm}^{-1}$ decreased and that at $1243 \mathrm{~cm}^{-1}$ increased, consistent with the reaction sequence proposed in Scheme 3. After the solution had been at reflux for $12 \mathrm{~h}$, excess freshly distilled aniline was added and the mixture stirred at room temperature for $24 \mathrm{~h}$. The solvent was removed in vacuo and the residue recrystallised from ethanol/water to give $N$-(4-methoxyphenyl)- $N$ '-phenylurea (310 mg, 95\%); mp $186-188^{\circ} \mathrm{C}\left(\right.$ lit. $\left.{ }^{45} 186-190{ }^{\circ} \mathrm{C}\right)$.

Butyl isocyanate. 3,4-Dibutylfuroxan $1 \mathrm{~h}(300 \mathrm{mg}, 1.52 \mathrm{mmol})$ was pyrolysed at $600{ }^{\circ} \mathrm{C}$ and the pyrolysate condensed onto sulfur dioxide. HPLC analysis of the reaction mixture showed that all the starting material had been consumed. The solution was then heated at reflux for $3 \mathrm{~h}$ and on cooling the presence of butyl isocyanate demonstrated by an IR peak at $2260 \mathrm{~cm}^{-1}$. An excess of aniline was added and the resulting solution stirred for $12 \mathrm{~h}$. Work up of the mixture afforded $\mathrm{N}$ butyl- $N$ '-phenylurea as white needles (from $\mathrm{CHCl}_{3} /$ pentane); mp and mixed mp $128-129{ }^{\circ} \mathrm{C}$ (lit. ${ }^{46} 130^{\circ} \mathrm{C}$ ); the IR spectrum of the product was indistinguishable from that of an authentic sample prepared from aniline and butyl isocyanate.

Methyl isocyanate. 3,4-Dimethylfuroxan $1 \mathbf{b}(650 \mathrm{mg}, 5.70 \mathrm{mmol})$ was pyrolysed at $550{ }^{\circ} \mathrm{C}$ and the pyrolysate condensed onto sulfur dioxide. After $3 \mathrm{~h}$ at reflux, freshly distilled aniline $(4 \mathrm{ml})$ was added and the solution heated at reflux for a further 10 minutes. $N$-Methyl- $N$ '-phenylurea (930 mg, 54\%) precipitated from the solution on cooling and was isolated as white platelets from ethanol; mp 149-150 ${ }^{\circ} \mathrm{C}\left(\right.$ lit. $\left.{ }^{47} 152-152{ }^{\circ} \mathrm{C}\right)$; IR (Nujol): v 3309, $3360(\mathrm{~N}-\mathrm{H}), 1700,1650(\mathrm{C}=\mathrm{O})$; Anal. Calcd. for $\mathrm{C}_{8} \mathrm{H}_{10} \mathrm{~N}_{2} \mathrm{O}: \mathrm{C}, 64.0 ; \mathrm{H}, 6.7 ; \mathrm{N}, 18.7$. Found: C, 64.2; H, 6.7; N, 18.6. The toluene was evaporated from the filtrate and the residue distilled under vacuum $\left(40^{\circ} \mathrm{C} / 0.05 \mathrm{mmHg}\right)$ to give a yellow liquid. HPLC analysis, using diphenylfuroxan 1a as internal standard, indicated the presence of dimethylfuroxan $1 \mathbf{a}(0.85 \mathrm{mmol}, 18 \%)$. Therefore the yield of $N$-methyl- $N$ '-phenylurea, based on consumed furoxan, was $74 \%$. In a parallel experiment the presence of methyl isocyanate was shown by an IR peak (in toluene) at $2270 \mathrm{~cm}^{-1}$. 
Isolation of acetohydroxamic acid from the hydrolysis of 5-methyl-1,3,2,4-dioxathiazole 2oxide (15b). 3,4-Dimethylfuroxan $1 \mathbf{b}(1.00 \mathrm{~g}, 8.77 \mathrm{mmol})$ was pyrolysed at $550{ }^{\circ} \mathrm{C}$ and the pyrolysate condensed onto sulfur dioxide. Diethyl ether and water were added and the reaction mixture shaken vigorously. A few drops were applied to a piece of filter paper saturated with aq. ferric chloride; an intense purple colour formed, consistent with the presence of the hydroxamic acid. The solvent was then removed in vacuo and the resulting yellow oil triturated with pentane to afford acetohydroxamic acid $(0.80 \mathrm{~g}, 61 \%)$; mp 89-91 ${ }^{\circ} \mathrm{C}\left(1 \mathrm{it} .{ }^{48} 86-88{ }^{\circ} \mathrm{C}\right)$.

FVP of 3,4-diphenylfuroxan in the absence of sulfur dioxide. 3,4-Dimethylfuroxan 1b (300 mg, $1.26 \mathrm{mmol}$ ) was pyrolysed at three temperatures $\left(550,700,800{ }^{\circ} \mathrm{C}\right.$ ) and the pyrolysate condensed onto hex-1-ene $(\sim 2 \mathrm{ml})$. In each case the composition of the reaction mixture was analysed by GC using diphenyl ether as internal standard, and the isoxazoline 9a isolated and its identity confirmed from its $\mathrm{mp}$ and mixed $\mathrm{mp}$. The $\mathrm{GC}$ product yields were as follows:- $550{ }^{\circ} \mathrm{C}$ : 98\% 9a, $<2 \%$ PhNCO; $700{ }^{\circ} \mathrm{C}: 95 \%$ 9a, 4\% PhNCO; $800{ }^{\circ} \mathrm{C}: 27 \%$ 9a, 37\% PhNCO. The pyrolysis at $800{ }^{\circ} \mathrm{C}$ proceeded with considerable charring.

Preparation of phenyl isothiocyanate by FVP of 3,4-diphenylfuroxan. 3,4-Diphenylfuroxan 1a (400 mg, $1.69 \mathrm{mmol}$ ) was pyrolysed at $550{ }^{\circ} \mathrm{C}$ and the pyrolysate condensed onto $N, N$ dimethylthioformamide $(1.5 \mathrm{~g}, 1.69 \mathrm{mmol})$ in dry diethyl ether $(\sim 2 \mathrm{ml})$. The mixture was allowed to warm to room temperature and, after standing for $3 \mathrm{~h}$, examined by IR spectroscopy. The IR spectrum showed the presence of phenyl isothiocyanate $\left(v 2050 \mathrm{~cm}^{-1}\right)$ and the co-product $N, N$-dimethylformamide $\left(v 1685 \mathrm{~cm}^{-1}\right)$. Freshly distilled aniline was added and the mixture stirred for $24 \mathrm{~h}$; the disappearance of the isothiocyanate was monitored by IR spectroscopy. $N, N^{\prime}$-diphenylthiourea (380 $\mathrm{mg}, 49 \%$ ) precipitated from the solution and was isolated as white platelets from an ethanol/water mixture; mp $152{ }^{\circ} \mathrm{C}$ (lit. ${ }^{49} 152{ }^{\circ} \mathrm{C}$ ). The IR spectrum was indistinguishable for that of an authentic sample prepared from phenyl isothiocyanate and aniline.

\section{Generation of alkanonitrile oxides}

Acetonitrile oxide (2b). 3,4-Dimethylfuroxan $\mathbf{1 b}(0.5 \mathrm{~g}, 84.4 \mathrm{mmol})$ was pyrolysed at $600{ }^{\circ} \mathrm{C}$ and the pyrolysate condensed onto deuterochloroform $(\sim 2 \mathrm{ml})$ at $-196{ }^{\circ} \mathrm{C}$. A second layer of deuterochloroform was distilled into the cold trap to form a 'sandwich'. After warming under dry nitrogen to $-78^{\circ} \mathrm{C}\left(\mathrm{CO}_{2} / \mathrm{Me}_{2} \mathrm{CO}\right.$ slush bath), the resulting solution was transferred to NMR tubes for spectroscopic study; IR $\left(\mathrm{CDCl}_{3}\right): v 2280(\mathrm{CNO})$; the NMR spectra at $-51{ }^{\circ} \mathrm{C}$ showed the presence of a $\sim 5: 1$ mixture of acetonitrile oxide $2 \mathbf{b}\left[\delta_{\mathrm{H}} 2.26 \mathrm{ppm}\left(\mathrm{CH}_{3}\right) ; \delta_{\mathrm{C}} 35.6\left(\mathrm{t},{ }^{1} \mathrm{~J} 48 \pm 2 \mathrm{~Hz}\right.\right.$, $\left.\mathrm{CN}), 0.8 \mathrm{ppm}\left(\mathrm{CH}_{3}\right)\right]$ and unreacted 3,4-dimethylfuroxan $\mathbf{1 b}\left[\delta_{\mathrm{H}} 2.40,2.21 \mathrm{ppm}\left(\mathrm{CH}_{3}\right) ; \delta_{\mathrm{C}} 154.4\right.$ $(\mathrm{C}-4), 112.7$ (C-3), 10.5, $\left.6.9 \mathrm{ppm}\left(\mathrm{CH}_{3}\right)\right]$. The spectra were unchanged after three days at $-78{ }^{\circ} \mathrm{C}$. After two days at room temperature the peaks for nitrile oxide $\mathbf{2 b}$ had disappeared and only those for furoxan $\mathbf{1 b}$ were detectable.

Propionitrile oxide (2c) was generated similarly by FVP of 3,4-diethylfuroxan $1 \mathrm{c}$ at $600{ }^{\circ} \mathrm{C} ;{ }^{1} \mathrm{H}$ $\left.\operatorname{NMR}\left(\mathrm{CDCl}_{3},-45{ }^{\circ} \mathrm{C}\right): \delta 2.61\left(\mathrm{q}, J=7.5 \mathrm{~Hz}, \mathrm{CH}_{2}\right), 1.30\left(\mathrm{t}, J=7.5 \mathrm{~Hz}, \mathrm{CH}_{3}\right) ;\right) ;{ }^{13} \mathrm{C}$ NMR $\left(\mathrm{CDCl}_{3},-45{ }^{\circ} \mathrm{C}\right): \delta 39.1\left(\mathrm{t},{ }^{1} \mathrm{~J} 42 \pm 2 \mathrm{~Hz}, \mathrm{CN}\right), 11.0 \mathrm{ppm}\left(\mathrm{CH}_{2}, \mathrm{CH}_{3}\right)$. After two days at room 
temperature the peaks for nitrile oxide 2c had disappeared and only those for furoxan 1c were detectable; ${ }^{1} \mathrm{H}$ NMR $\left(\mathrm{CDCl}_{3}\right): \delta 2.71\left(\mathrm{q}, J=7.5 \mathrm{~Hz}, \mathrm{CH}_{2}\right), 2.55\left(\mathrm{q}, J=7.5 \mathrm{~Hz}, \mathrm{CH}_{2}\right), 1.30(\mathrm{t}, J=$ $\left.7.5 \mathrm{~Hz}, \mathrm{CH}_{3}\right), 1.18\left(\mathrm{t}, J=7.5 \mathrm{~Hz}, \mathrm{CH}_{3}\right) ;{ }^{1} \mathrm{H}$ NMR $\left(\mathrm{CDCl}_{3}\right): \delta 158.5(\mathrm{C}-4), 116.5(\mathrm{C}-3), 19.0$, 15.7, $\left(\mathrm{CH}_{2}\right), 10.6,9.5\left(\mathrm{CH}_{3}\right)$.

\section{Dimerisation of acetonitrile oxide (2b) to 3,4-dimethylfuroxan (1b)}

The conversion of acetonitrile oxide $\mathbf{2 b}$ into 3,4-dimethylfuroxan $\mathbf{1 b}$ was monitored by ${ }^{1} \mathrm{H}$ NMR spectroscopy in $\mathrm{CDCl}_{3}$ at $23.0 \pm 0.5{ }^{\circ} \mathrm{C}$. A solution of $\mathbf{2 b}$ in $\mathrm{CDCl}_{3}$ was prepared by $\mathrm{FVP}$ of furoxan $\mathbf{1 b}(0.5 \mathrm{~g}, 4.39 \mathrm{mmol})$ at $650{ }^{\circ} \mathrm{C}$, as described above, and then stored at $-78{ }^{\circ} \mathrm{C}$. A portion of the acetonitrile oxide solution $(0.50 \mathrm{ml})$ was added to an NMR tube containing dioxan $(10.0 \mu \mathrm{l})$ as internal standard, and the NMR spectrum recorded at $-40{ }^{\circ} \mathrm{C}$ in order to determine the initial concentrations. The reaction was then initiated by raising the temperature to $23{ }^{\circ} \mathrm{C}$ and spectra recorded at 5-minute intervals. After one hour the sample was allowed to warm to room temperature, left for two days, and the final spectrum then recorded. The formation of the furoxan, rather than the consumption of the nitrile oxide, was used to follow the progress of the reaction as the integral of the furoxan methyl signal at $\delta_{\mathrm{H}}=2.40 \mathrm{ppm}$ could be measured more accurately than that of the nitrile oxide at $\delta_{\mathrm{H}}=2.26 \mathrm{ppm}$. The concentrations $\left[\mathrm{F}_{t}\right]$ of furoxan $\mathbf{2 b}$ were measured at time ' $\mathrm{t}$ ' by comparison with the dioxan signal at $\delta_{\mathrm{H}}=3.75 \mathrm{ppm}$. A typical experiment gave the following values for time/minutes and $\left[\mathrm{F}_{t}\right] / \mathrm{mol}_{\mathrm{dm}}{ }^{-3}: 0$ [0.226], $5[0.258]$, 10 [0.278], 15 [0.314], 20 [0.306], 25 [0.334], 30 [0.348], 35 [0.400], 40 [0.400], 45 [0.430], 50 $[0.440], 55[0.446], 2$ days [0.696]. From a plot of $\left[\mathrm{F}_{\infty}-\mathrm{F}_{t}\right]^{-1} v s$ time $t$, the second order rate constant was determined as $k=5.95 \pm 0.2 \times 10^{-4} \mathrm{~mol}^{-1} \mathrm{dm}^{3} \mathrm{~s}^{-1}$. A repeat experiment gave $k=$ $6.19 \pm 0.2 \times 10^{-4} \mathrm{~mol}^{-1} \mathrm{dm}^{3} \mathrm{~s}^{-1}$, giving a mean value of $6.1 \pm 0.2 \times 10^{-4} \mathrm{~mol}^{-1} \mathrm{dm}^{3} \mathrm{~s}^{-1}$.

\section{Flash vacuum pyrolysis (FVP) of 1,2,3-triazole 1-oxides}

FVP of 2,4,5-triphenyl-1,2,3-triazole 1-oxide (25a). 2,4,5-Triphenyl-1,2,3-triazole 1-oxide 25a (500 mg, $1.60 \mathrm{mmol}$ ) was pyrolysed at $650{ }^{\circ} \mathrm{C}$ and the pyrolysate condensed onto diethyl fumarate $(3.0 \mathrm{~g})$ in sodium dried toluene $(5 \mathrm{ml})$. On warming the solution was examined by IR spectroscopy, which showed no peak at $\sim 2330 \mathrm{~cm}^{-1}$ attributable to benzonitrile oxide. The toluene and diethyl fumarate were removed in vacuo. TLC and ${ }^{1} \mathrm{H}$ NMR spectroscopy showed the presence of unreacted 25a; diethyl trans-3-phenyl-2-isoxazoline-4,5-dicarboxylate 13 was not detectable.

FVP of 4,5-dimethyl-2-phenyl-1,2,3-triazole 1-oxide (25b). 4,5-dimethyl-2-phenyl-1,2,3triazole 1-oxide $25 \mathbf{b}(250 \mathrm{mg}, 1.32 \mathrm{mmol})$ was pyrolysed at $650{ }^{\circ} \mathrm{C}$ and the pyrolysate condensed onto hex-1-ene $(5 \mathrm{ml})$. After warming to room temperature the hexene was removed in vacuo to leave a brown oil. TLC examination showed the presence of five components, one of which was the starting material. Comparison of the $\mathrm{R}_{\mathrm{f}}$ values with that of authentic 5-butyl-3-methyl-2isoxazoline showed that it was not present. Chromatography (alumina, $\mathrm{Et}_{2} \mathrm{O}$ /pentane) gave a brown solid $(85 \mathrm{mg})$ which was recrystallised from methanol to yield 1,2-di(5-methyl-2-phenyl1,2,3-triazol-4-yl)ethane $28(37 \%)$ as white platelets; mp $138-139{ }^{\circ} \mathrm{C} ;{ }^{1} \mathrm{H} \mathrm{NMR}\left(\mathrm{CDCl}_{3}\right): \delta 8.05$ - 
$7.21(\mathrm{~m}, 10 \mathrm{H}, \mathrm{PhH}), 3.10\left(\mathrm{~s}, 4 \mathrm{H}, \mathrm{CH}_{2}\right), 2.21\left(\mathrm{~s}, 6 \mathrm{H}, \mathrm{CH}_{3}\right) ;{ }^{1} \mathrm{C} \mathrm{NMR}\left(\mathrm{CDCl}_{3}\right): \delta 146.5,143.5(\mathrm{C}-$ 4,5), 139.8, 129.1, 126.5, 118.1 (ArC), $24.1\left(\mathrm{CH}_{2}\right), 9.8\left(\mathrm{CH}_{3}\right)$; $\mathrm{MS}(\mathrm{EI}): \mathrm{m} / \mathrm{z}(\%) 345\left(\mathrm{M}^{+}+1,18\right)$, 344 (M+, 83), 185 (16), 173 (15), 172 (100), 91 (27), 77 (18); HRMS (EI): Calcd. for $\mathrm{C}_{20} \mathrm{H}_{20} \mathrm{~N}_{6}$ : $M$ 344.1749. Found: $m / z$ 344.1745.

\section{Acknowledgements}

We are grateful to the EPSRC for research and maintenance (W.R.M.) grants. Our thanks are due to $\mathrm{H}$. McNab for valuable discussions and access to FVP facilities.

\section{References}

1. For reviews and monographs of nitrile oxide chemistry see: (a) Grundmann, C; Grünanger, P. The Nitrile Oxides, Springer-Verlag: Heidelberg, 1971. (b) Caramella, P; Grünanger, P. in 1,3-Dipolar Cycloaddition Chemistry, Padwa, A.; Wiley: New York, 1984, Ch 3. (c) Jäger, V.; Colinas, P.A. In Synthetic Applications of 1,3-Dipolar Cycloaddition Chemistry toward Heterocycles and Natural Products, Padwa, A.; Pearson, W. H.; Wiley: New York, 2002, Ch. 6. (d) Torssell, K. B. G. Nitrile Oxides, Nitrones and Nitronates in Organic Synthesis, VCH: Weinheim, 1988. (e) Nitrile Oxides, Nitrones and Nitronates in Organic Synthesis, $2^{\text {nd }}$ Edn. Feuer, H., Wiley: New Jersey, 2008.

2. For examples of nitrile oxide generation from furoxans see: (a) Ackrell, J.; Altaf-ur-Rahman, M.; Boulton, A. J.; Brown, R. C. J. Chem. Soc., Perkin Trans. 1 1972, 1587. (b) Dondoni, A.; Barbaro, G.; Battaglia, A.; Giorianni, P. J. Org. Chem. 1972, 37, 3196. (c) Chapman J. A.; Crosby, J.; Cummings, C. A.; Rennie, R. A.; Paton, R. M. J. Chem. Soc., Chem. Commun. 1976, 240. (d) Britelli, D. R.; Boswell, G. A. J. Org. Chem. 1981, 46, 316. (e) Whitney, R. A.; Nicholas, E. S. Tetrahedron Lett. 1981, 22, 3371. (f) Curran, D. P.; Fenk, C. J. J. Am. Chem. Soc. 1985, 107, 6023. (g) Barnes, J. F.; Barrow. M. J.; Harding, M. M.; Paton, R. M.; Ashcroft, P. L.; Crosby, J.; Joyce, C. J. J. Chem. Res (S) 1979, 314. (h) Shimizu, T.; Hayashi, Y.; Taniguchi, T.; Teramura, K. Tetrahedron 1985, 41, 727. (i) Ashcroft, P. L.; Barnes, J. F.; Barron, K.; Bradbury, R.; Crosby, J.; Joyce, C. J.; Harding, M. M.; Holmes, D. R.; Milner, J. A.; Paton, R. M. J. Chem. Soc., Perkin Trans. 1 1986, 601. (j) Pasinszki, T.; Westwood, N. P. C. J. Phys. Chem. A 1998, 102, 4939. (k) Karmakar, D.; Prajapati, D.; Sandhu, J. S. Synth. Commun. 1998, 28, 2415. (1) Kulikov, A. S.; Epishina, M. A.; Ovchinnikov, I. V.; Makhova, N. N. Russ. Chem. Bull. 2007, 56, 1580.

3. (a) Gabriel, S.; Koppe, M. Chem. Ber. 1886, 19, 1145. (b) von Auwers, K.; Meyer, V. Chem. Ber. 1889, 22, 705.

4. (a) Prokudin, V. G.; Nazin, G. M.; Dubkhin, V. V. Kinetika i Kataliz 1981, 22, 871. (b) Oyumi, Y.; Brill, T. B. Combust. Flame 1986, 65, 313. (c) Pasinszki, T.; Westwood, N. P. C. 
J. Chem. Soc., Chem. Commun. 1995, 1901. (d) Pasinszki, T.; Westwood, N. P. C. J. Phys. Chem. A 1996, 100, 16856. (e) Pasinszki, T.; Westwood, N. P. C. J. Phys. Chem. A 2001, 105, 1244.

5. Shimizu, T.; Hayashi, Y.; Teramura, K. J. Org. Chem. 1983, 48, 3053.

6. (a) Butler, R. N.; Cunningham, D.; Marren, E. G.; McArdle, P. Tetrahedron Lett. 1988, 29, 3331. (b) Butler, R. N.; Cunningham, D.; Marren, E. G.; McArdle, P.; O’Shea, D. F. J. Chem. Res (S) 1992, 256.

7. For reviews of FVP see: (a) McNab, H. Contemporary Org. Synth. 1996, 3, 373. (b) Yranzo, G. I.; Moyano, E. L. Current Org. Chem. 2004, 8, 1071. (c) McNab, H. Aldrichimica Acta 2004, 2, 2677

8. For recent some recent synthetic applications of FVP see: (a) Dosa, P. I.; Gu, Z.; Hager, D.; Karney, W. L.; Vollhardt, K. P. C. Chem. Commun. 2009, 1967. (b) McNab, H.; Morrow, M.; Parsons, S.; Shannon, D. A.; Withell, K. Org. Biomol. Chem. 2009, 4936. (c) Aitken, R. A.; Garnett, A. N. New J. Chem. 2009, 33, 2402. (d) Amsharov, K. Y.; Kabdulov, M. A.; Jansen, M. Eur. J. Org. Chem. 2009, 6328. (e) Moyano, E. L.; Eimer, G. A.; Lucero, P. L.; Chanquia, C. M.; Herrero, E. R.; Yranzo, G. I. Applied Catal. A 2010, 373, 98. (f) Gaywood, A. P.; Hill, L.; Imam, S. H.; McNab, H.; Neumajor, G.; O’Neill, W. J.; Matyus, P. New J. Chem. 2010, 34, 236.

9. Mitchell, W. R.; Paton, R. M. Arkivoc 2009, (xiv), 200.

10. Preliminary reports: (a) Mitchell, W. R.; Paton, R. M. Tetrahedron Lett. 1979, 20, 2443. (b) Mitchell, W. R.; Paton, R. M Chem. Ind. (London, UK) 1980, 665.

11. For reviews of furoxan chemistry see: (a) Gasco, A.; Boulton, A. J. Adv. Heterocycl. Chem. 1981, 29, 251. (b) Paton, R. M. In Comprehensive Heterocyclic Chemistry II; Katritzky, A. R.; Rees, C. W.; Scriven, E. F. V.; Pergamon: Oxford, 1996, Ch. 4.05. (c) Sheremetev, A. B.; Makhova, N. N.; Friedrichsen, W. Adv. Heterocycl. Chem. 2001, 78, 65. (d) Paton, R. M. Science of Synthesis 2004, 13, 183.

12. Boyer, J. H.; Reinisch, R. F.; Danzig, M. J.; Stoner, G. A.; Sahhar, F. J. Am. Chem. Soc. 1955, 77, 5688.

13. Mukaiyama, T.; Hoshino, T. J. Am. Chem. Soc. 1960, 82, 5339.

14. Kinney, C. R.; Smith, E. W.; Wooley, B. L.; Willey, A. R. J. Am. Chem. Soc. 1933, 55, 3418. 15. Rahman, A.; Clapp, L. B. J. Org. Chem. 1976, 41, 122.

16. Brandi, A.; De Sarlo, F.; Guarna, A. J. Chem. Soc., Perkin Trans. 1 1976, 1827.

17. (a) Christl, M.; Warren, J. P.; Hawkins, B. L.; Roberts, J. D. J. Am. Chem. Soc. 1973, 95, 4392. (b) De Sarlo, F.; Brandi, A.; Guarna, A. J. Magn. Reson. 1982, 50, 64. (c) Makhova, N. N.; Ovchinnikov, I. V.; Dubonos, V. G.; Strelenko, Y. A.; Khmelnitskii, L. I. Mendeleev Commun. 1992, 91. (d) Kelly, D. R.; Baker, S. C.; King, D. S.; de Silva, D. S.; Lord, G; Taylor, J. P. Org. Biomol. Chem. 2008, 6, 787.

18. (a) Dondoni, A.; Mangini, A.; Ghersetti, S. Tetrahedron Lett. 1966, 4789. (b) Barbaro, G.; Battaglia, A.; Dondoni, A. J. Chem. Soc. B 1970, 588. 
19. Pasinszki, T.; Hajgato, B.; Havasi, B.; Westwood, N. P. C. Phys. Chem. Chem. Phys. 2009, 11, 5263.

20. For an example of such a coupling for a 3-methyl-2-isoxazoline see: Jones, R. A.; Marriott, M. T. P. Heterocycles 1980, 14, 185.

21. Burk, E. H.; Carlos, D. D. J. Heterocycl. Chem. 1970, 7, 177.

22. Trickes, G.; Meier, H. Angew. Chem. Int. Ed. Engl. 1977, 16, 555.

23. Klamann, D.; Koser, W.; Weyerstahl, P.; Fligge, M. Chem. Ber. 1965, 98, 1831.

24. Franz, J. E.; Pearl, H. K. J. Org. Chem. 1976, 41, 1296.

25. Grundmann, C.; Kochs, P. Angew. Chem. Int. Ed. Engl. 1970, 9, 555.

26. Taylor, G. A. J. Chem. Soc., Perkin Trans. 1 1985, 1181.

27. Huisgen, R.; Mack, W.; Anneser, E. Angew. Chem. 1961, 73, 656.

28. Barnes, J. F.; Harding, M. M.; Paton, R. M.; Ashcroft, P. L.; Bradbury, R.; Crosby, J.; Joyce, C. J.; Holmes, D.; Milner, J. A. J. Chem. Soc., Perkin Trans. 1 1983, 293.

29. Himmel, H.-J.; Konrad, S.; Friedrichsen, W.; Rauhut, G. J. Phys. Chem. A 2003, 107, 6731.

30. Bird, C. W. Tetrahedron 1992, 48, 335.

31. Bird, C. W. Tetrahedron 1993, 49, 8441.

32. Clark, B. A. J.; Evans, T. J.; Simmonds, R. G. J. Chem. Soc., Perkin Trans. 1 1975, 1803.

33. (a) Butler, R. N.; Cunningham, D.; Marren, E. G.; McArdle, P. J. Chem. Soc., Chem. Commun. 1987, 706. (b) Butler, R. N.; Cunningham, D.; Marren, E. G.; McArdle, P. J. Chem. Soc., Perkin Trans. 1 1990, 3321.

34. Geigy, J. R. Fr. Patent 1559 131; Chem. Abstr. 1969, 71, 12445.

35. Buchaka, S. M.; Kuznetsov, M. A.; Schantl, J. G. Chem. Heterocycl. Cmpd. Engl. Transl. 2005, 41, 1321.

36. Sukumaran, K. B.; Satish, S.; George, M. V. Tetrahedron 1974, 30, 445.

37. Wieland, H.; Semper, L. Ann. Chem. 1908, 358, 36.

38. Emmons, W. D.; Freeman, J. P. J. Org. Chem. 1957, 22, 456.

39. Boulton, A. J.; Hadjimihalakis, P.; Katritzky, A. R.; Majid Hamid, A. J. Chem. Soc. (C) 1969, 1901.

40. Rheinboldt, H.; Dewald, M.; Jansen, F.; Schmitz-Dumont, O. Ann. Chem. 1927, 451, 161.

41. Ponzio, G. Gazz. Chim. Ital. 1898, 28, 176.

42. Bianchi, G.; Grünanger, P. Tetrahedron 1965, 21817.

43. Dictionary of Organic Compounds, Eyre and Spottiswoode Ltd: London, 1965.

44. Sauer, J.; Meyer, K. Tetrahedron Lett. 1968, 325.

45. Conrad, L. Helv. Chim. Acta 1938, 21, 1127.

46. Boehmer, J. H. Rec. Trav. Chim. Pays-Bas 1936, 55, 386.

47. Degner, O.; Pechman, H. V. Chem. Ber. 1897, 30, 650.

48. Hurd, C. D.; Cochran, P. B. J. Am. Chem. Soc. 1923, 45, 515.

49. Baltas, M.; Raouf-Benchekroun, K.; De Blic, A.; Cazaux, L.; Tisnes, P.; Gorrichon, L.; Hussein, K.; Barthelat, J.-C. Tetrahedron 1996, 52, 14865. 